NBER WORKING PAPER SERIES

\title{
STRONGER RISK CONTROLS, LOWER RISK: EVIDENCE FROM U.S. BANK HOLDING COMPANIES
}

\author{
Andrew Ellul \\ Vijay Yerramilli \\ Working Paper 16178 \\ http://www.nber.org/papers/w16178
NATIONAL BUREAU OF ECONOMIC RESEARCH
1050 Massachusetts Avenue
Cambridge, MA 02138 \\ July 2010
}

We would like to thank Rajesh Aggarwal, Utpal Bhattacharya, Charles Calomiris, Mark Carey, Michel Crouhy, Mark Flannery, Laurent Fresard, Bill Keeton, Radhakrishnan Gopalan, Nandini Gupta, Jean Helwege, Christopher Hennessy, Tullio Jappelli, Steven Kaplan, Anil Kashyap, Jose Liberti, Marco Pagano, Rich Rosen, Amit Seru, Phil Strahan, René Stulz, Anjan Thakor, David Thesmar, Greg Udell, James Vickery, Vikrant Vig, Jide Wintoki, and seminar participants at the CEPR Summer Symposium in Gerzensee, European School of Management and Technology (Berlin), Indiana University, the NBER Sloan Project Conference on Market Institutions and Financial Market Risk and our discussants Charles Calomiris and Michel Crouhy, the Southwind Finance Conference at the University of Kansas and our discussant Bill Keeton, and University of Naples Federico II for their helpful comments and suggestions. We also thank our research assistants, Robert Gradeless and Shyam Venkatesan,for their diligent effort. All remaining errors are our responsibility. The views expressed herein are those of the authors and do not necessarily reflect the views of the National Bureau of Economic Research.

NBER working papers are circulated for discussion and comment purposes. They have not been peerreviewed or been subject to the review by the NBER Board of Directors that accompanies official NBER publications.

(C) 2010 by Andrew Ellul and Vijay Yerramilli. All rights reserved. Short sections of text, not to exceed two paragraphs, may be quoted without explicit permission provided that full credit, including $\odot$ notice, is given to the source. 
Stronger Risk Controls, Lower Risk: Evidence from U.S. Bank Holding Companies

Andrew Ellul and Vijay Yerramilli

NBER Working Paper No. 16178

July 2010

JEL No. G01,G21,G32

\begin{abstract}
$\underline{\text { ABSTRACT }}$
In this paper, we investigate whether U.S. bank holding companies (BHCs) with strong and independent risk management functions have lower enterprise-wide risk. We hand-collect information on the organizational structure of the risk management function at the 74 largest publicly-listed BHCs, and use this information to construct a Risk Management Index (RMI) that measures the strength of organizational risk controls at these institutions. We find that BHCs with a high RMI in the year 2006 (i.e., before the onset of the financial crisis) had lower exposure to private-label mortgage-backed securities, were less active in trading off-balance sheet derivatives, had a smaller fraction of non-performing loans, and had lower downside risk during the crisis years (2007 and 2008). In a panel spanning the 9 year period 2000--2008, we find that BHCs with higher RMIs have lower enterprise-wide risk, after controlling for size, profitability, a variety of risk characteristics, corporate governance, CEO's pay-performance sensitivity, and BHC fixed effects. This result holds even after controlling for any dynamic endogeneity between risk and internal risk controls. Overall, these results suggest that strong internal risk controls are effective in restraining risk-taking behavior at banking institutions.
\end{abstract}

\author{
Andrew Ellul \\ Kelley School of Business \\ Finance Department \\ Indiana University \\ 1309 E. Tenth Street \\ Bloomington, IN 47405 \\ and LSE Financial Markets Group \\ anellul@indiana.edu \\ Vijay Yerramilli \\ Bauer College of Business \\ University of Houston \\ 240D Melcher Hall \\ Houston, TX 77204 \\ vyerramilli@bauer.uh.edu
}


"The failure to appreciate risk exposures at a firmwide level can be costly. For example, during the recent episode, the senior managers of some firms did not fully appreciate the extent of their firm's exposure to U.S. subprime mortgages. They did not realize that, in addition to the subprime mortgages on their books, they had exposures through the mortgage holdings of off-balance-sheet vehicles, through claims on counterparties exposed to subprime, and through certain complex securities..."

- Chairman of the Federal Reserve, Ben Bernanke ${ }^{1}$

\section{Introduction}

There is wide-spread agreement on the proximate causes of the current financial crisis: banks had substantial exposure to subprime risk on their balance sheets, and these risky assets were funded mostly by short-term market borrowing (Kashyap et al. (2008), Acharya et al. (2009)). As a result, what began as a housing crisis in the United States soon turned into a full-blown global financial crisis. Among the explanations for why banks exposed themselves to such risks, a prominent explanation that has been advanced by policymakers, bank supervisors and academics is that there was a failure of risk management at banks. ${ }^{2}$ The argument seems to be that traders and other bank executives with high-powered payfor-performance schemes were exploiting deficiencies in the internal control systems, and risk managers were unable or powerless to restrain them (Senior Supervisors Group (2008), Kashyap et al. (2008)).

In this paper, we focus on the organizational structure of the risk management function at bank holding companies (BHCs) in the United States. The key question we examine is whether BHCs that had strong internal risk controls in place had lower enterprise-wide risk, after controlling for the underlying risk of the BHCs' business activities. To this end, we construct an innovative risk management index that measures the importance attached to the risk management function within the organization, and how well information on risk from the different business segments is conveyed to the BHC's board of directors. We gauge the importance attached to the risk management function by examining if the $\mathrm{BHC}$ has a designated Chief Risk Officer (CRO) and how powerful the CRO is within the organization; specifically, whether the CRO is among the top five highly paid executives, and how the CRO's pay compares with that of the Chief Executive Officer (CEO). Similarly, to gauge how

\footnotetext{
${ }^{1}$ Comments from his special address delivered at the $44^{\text {th }}$ annual Conference on Bank Structure and Competition, held at the Federal Reserve of Chicago in May 2008.

${ }^{2}$ Stulz (2008) characterizes a failure of risk management as one of the following: failure to identify or correctly measure risks, failure to communicate risk exposures to the top management, and failure to monitor or manage risks adequately.
} 
well quantitative and qualitative information on risk is shared between the top management and business segments, we examine whether the directors serving on the BHC's designated board committee to oversee risk have prior banking experience, and the frequency of the meetings held by the BHC's designated board risk committee.

Our research question is motivated by the idea that a strong and independent risk management function is necessary to effectively manage risk in modern-day banking institutions. This is because deposit insurance protection and implicit too-big-to-fail guarantees weaken the incentives of debtholders to impose market discipline, while the ever increasing complexity of modern-day banking institutions and the ease with which their risk profiles can be altered by traders and security desks makes it difficult for supervisors to regulate risks (Acharya et al. (2009)). The increasing complexity of modern-day banking institutions also makes it difficult to measure risk and to communicate risk objectives to business segments in easily quantifiable terms. As Stulz (2008) notes, once risk management moves away from established quantitative models, it becomes easily embroiled in intra-firm politics; e.g., traders whose bonuses depend on the risks they take, may be at cross-purposes with the risk officer. Therefore, the outcome for the institution depends on how strong and independent the risk management function is.

Policymakers and supervisors seem to echo this view. Based on its discussions with the largest financial institutions, the Senior Supervisors Group (2008) has concluded that what distinguished well-managed institutions that fared well during the crisis was that they had strong and independent risk management functions, and that there was a robust dialogue between their senior management team and business segments regarding organization-wide risk preferences. ${ }^{3}$ In particular, the SSG report highlights specific weaknesses in risk management practices that contributed to heavy losses at institutions that performed poorly during the crisis: excessive reliance on external credit rating agencies and backward-looking measures of risk, and failure to conduct forward-looking stress tests $;^{4}$ failure to identify correlation risk; ${ }^{5}$ and underestimation of liquidity risk.

Our specific focus on BHCs is motivated by three important considerations. First, a typical BHC is comprised of several independent subsidiaries, each with its own management and board of directors, involved in a wide variety of financial activities. This kind of an organizational structure enhances the importance of an enterprise-wide risk management

\footnotetext{
${ }^{3}$ The Senior Supervisors Group (SSG) is a group of supervisory agencies from France, Germany, Switzerland, the United Kingdom, and the United States.

${ }^{4}$ Some institutions tended to assume that they could apply the low historical return volatility of corporate credits rated 'Aaa' to super-senior tranches of CDOs, a more novel instrument that rating agencies had likewise rated 'Aaa'.

${ }^{5}$ For example, several institutions assigned zero net risk to negative basis trades, where they held long position in a corporate bond combined with a protection in the form of a credit default swap (CDS), under the assumption that correlation between bond prices and CDS prices would follow historical relationships.
} 
mechanism that can identify and manage risks on a consolidated basis. Second, most BHCs are publicly listed on stock exchanges and file periodic reports (such as 10-K statements, and proxy statements) with the Securities and Exchange Commission (SEC), from which we are able to collect information on their risk management structure. Third, because they are regulated by the Federal Reserve and the FDIC, BHCs are required to report detailed financial information on a quarterly basis. Apart from information on the balance sheet and income statement items, we are also able to obtain detailed information on usage of derivatives and off-balance sheet activities.

We obtain our data from several sources. We hand-collect data on the organizational structure of risk management of BHCs from their 10-K statements, proxy statements, and annual reports. Given the effort involved in hand-collection and validation of information, we restrict ourselves to the 100 largest BHCs, in terms of the book value of their assets, at the end of 2007 (which accounted for $92 \%$ of the total assets of the banking system). Because some these BHCs are not publicly listed, and hence do not submit 10-K and proxy statements, the sample reduces to the largest 74 publicly-listed BHCs (which accounted for $78 \%$ of the total assets of the banking system). We hand-collect this information for the nine year period, 1999-2007, and use it construct a Risk Management Index (RMI). Financial information of BHCs is obtained from the FR Y-9C reports that they file with the Federal Reserve System. We use three different measures of enterprise-wide risk: aggregate risk, downside risk and tail risk. We use the standard deviation of a BHC's excess weekly return (i.e., weekly return on the BHC's stock less the weekly return on the S\&P500) over the calendar year as a proxy for its aggregate risk during the year (see Demsetz et al. (1997) and Laeven and Levine (2009)). ${ }^{6}$ We proxy for downside risk using the mean implied volatility estimated using put options written on the BHC's stock (Bali and Hovakimian (2009), Cremers and Weinbaum (2008) and Xing et al. (2008)). ${ }^{7}$ We proxy for tail risk using the marginal expected shortfall (MES) measure proposed by Acharya et al. (2009), which is defined as the negative of the average return on the BHC's stock over the $5 \%$ worst days for the S\&P500 during the year. We obtain data on stock returns from CRSP, and data on option prices and implied volatilities from the OptionMetrics database.

As a preamble to our analysis, and in keeping with the motivation of our paper, we begin by examining whether BHCs that had strong internal risk controls in place before the onset of the financial crisis fared better during the crisis years, 2007 and 2008. To answer this question, we estimate cross-sectional regressions in which the main independent variable

\footnotetext{
${ }^{6}$ Our results hold even if we use the standard deviation of weekly raw returns as a measure of aggregate risk.

${ }^{7}$ Another alternative is to estimate a BHC's downside risk using the spreads of its credit default swaps (CDS). However, we were able to obtain CDS spread information from Bloomberg for only 20 BHCs in our sample, as opposed to information on option implied volatilities which is available for 49 BHCs. Hence, we use the mean implied volatility estimated from put options as the measure of downside risk.
} 
is the BHC's RMI in 2006, and the outcome variables are performance measures in 2007 and 2008. The reason we choose RMI in 2006 as the independent variable is because the SSG report specifically highlights that institutions with strong risk management functions identified risks and started taking corrective actions as early as in 2006, when it was easier to offload holdings of mortgage-backed securities and CDOs, and was relatively cheaper to hedge risks. Consistent with the idea that BHCs with stronger internal risk controls were more judicious in their risk taking behavior, we find that BHCs with a high 2006 RMI had lower exposure to private-label mortgage-backed securities and risky trading assets, were less active in trading off-balance sheet derivative securities, and had a smaller fraction of non-performing loans during the crisis years. Moreover, BHCs with a high 2006 RMI fared (weakly) better in terms of stock return performance, and had lower implied volatilities during the crisis years.

Next, we examine a panel spanning the 9 year period from 2000-2008 to investigate whether BHCs with stronger risk controls had lower enterprise-wide risk, after controlling for the underlying risk profile of the BHC's business activities. In these panel regressions, we are better able to control for unobserved (time-invariant) BHC characteristics by including $\mathrm{BHC}$ fixed effects. After controlling for various BHC characteristics like size, profitability, asset and liability composition including capital ratios, other risk characteristics, CEO's pay-performance sensitivity, and corporate governance, we find that BHCs with stronger risk controls (i.e., higher values of RMI) in the previous year had lower downside risk, lower tail risk, and lower aggregate risk in the current year. In terms of economic significance, a one standard deviation increase in RMI is associated with 0.43 standard deviation decrease in downside risk, a 0.62 standard deviation decrease in tail risk, and a 0.6 standard deviation decrease in aggregate risk. We must emphasize that our panel regression includes year fixed effects as well as BHC fixed effects. Thus, we are controlling for time-invariant unobserved heterogeneity across BHCs. Our results reflect a within-BHC decrease in enterprise-wide risk from a strengthening of the risk management function.

One concern with the fixed effects panel regression model is that the negative association between risk and RMI may be driven by some unobserved time-varying omitted variable that jointly determines both risk and the choice of risk controls, or by the dynamic endogeneity between risk and RMI; i.e., causation between risk and RMI could run both ways such that past risk determines both current risk and choice of internal risk controls. This can bias our inferences depending on how causation affects the choice of RMI. It is possible that BHCs exposed to greater risk choose stronger risk management systems, which should bias against us finding a negative association between BHC Risk and RMI. ${ }^{8}$ Alternatively, it is possible

\footnotetext{
${ }^{8}$ The hypothesis follows from theories which suggest that firms that are more likely to experience financial distress should also be more aggressive in managing their risks (Smith and Stulz (1985), Froot et al. (1993)). For empirical evidence on this in the banking sector, see Purnanandam (2007), who shows that banks with
} 
that the underlying risk culture of the BHC determines both the choice of the risk and the strength of the risk management system; i.e., conservative BHCs take lower risks and put in place stronger risk management systems, while aggressive BHCs take higher risks and also have weaker internal risk controls. If the risk-culture hypothesis is correct, it will tend to exaggerate the positive association between BHC risk and RMI.

To deal with the dynamic endogeneity problem, we use a dynamic panel GMM estimator developed by Arellano and Bond (1991), that enables us to use the information from the BHC's history, in the form of lags of risk and other BHC characteristics, to provide instruments for identifying the relationship between RMI and risk. We choose a specification in which historical risk measures and other BHC characteristics that are lagged three periods or more are available for use as exogenous instruments for the current RMI. Our estimation results confirm the validity of instruments. More importantly, they show that BHCs with strong internal risk controls have lower enterprise-wide risk, even after controlling for the dynamic endogeneity between risk and RMI. ${ }^{9}$

Finally, we also examine if the stock market rewards or penalizes BHCs that have strong internal risk controls. If strong internal risk controls cause the BHC to forgo profitable but risky activities like asset management or derivatives trading, then it is possible that the stock market penalizes BHCs with high RMI. On the other hand, if strong risk controls can help a BHC avoid taking on excessive idiosyncratic risk, then the stock market should reward BHCs with high RMI. To test these hypotheses, we use the BHC's Sharpe ratio as a measure of the risk-adjusted return on the BHC's stock, and estimate panel regressions to examine how the Sharpe ratio varies with RMI. Our analysis indicates that, all else equal, Sharpe ratios are higher for BHCs with high RMI; i.e., the stock market rewards BHCs with strong internal risk controls. This result continues to hold even after we correct for any dynamic endogeneity between stock valuation and RMI, using the dynamic panel GMM estimator.

To summarize, our results support the idea that strong and independent risk controls lower enterprise-wide risk in banking institutions. BHCs with strong risk management functions in place before the onset of the financial crisis were more judicious in their exposure to risky financial instruments, and generally fared better during the crisis period. In a panel spanning 9 years, we find that BHCs with stronger internal risk controls had lower downside risk, lower tail risk, and lower aggregate risk, after controlling for size, profitability, asset and liability composition, governance, executive compensation, and unobserved heterogeneity using BHC fixed effects. This result is robust to controlling for any dynamic endogeneity

higher probability of financial distress manage their interest rate risk more aggressively.

${ }^{9}$ We obtain qualitatively similar results when we employ the "System GMM" estimator initially proposed by Arellano and Bover (1995), and further developed by Blundell and Bond (1998). 
between risk and strength of internal risk controls.

Our paper makes three important contributions. First, it highlights that weakening risk management at financial institutions may have contributed to the excessive risk-taking behavior that brought about the financial crisis. To the best of our knowledge, we are the first to show that banks with strong internal risk controls in place before the onset of the financial crisis were more judicious in exposing themselves to private-label mortgage-backed securities, risky trading assets and off-balance sheet derivative trading activity. Moreover, they also generally fared better during the crisis years. These results are related to the finding in Keys et al. (2009) that lenders with relatively powerful risk managers, as measured by the risk manager's share of the total compensation given to the five highest-paid executives in the institution, had lower default rates on the mortgages they originated. Another prominent argument that has been advanced to explain the risk-taking behavior of banks leading up to the financial crisis is that executives at banks had poor incentives. However, Fahlenbrach and Stulz (2009) find no evidence in support of this argument. In fact, they find that banks with CEOs whose incentives were better aligned with the interests of their shareholders actually performed worse during the credit crisis. Further, option compensation did not have an adverse impact on bank performance during the crisis.

Second, our paper contributes to the large literature that examines risk-taking by banks. Past research has examined the impact of deposit insurance and competition (Keeley (1990), Hellmann et al. (2000), Demirgüç-Kunt and Detragiache (2002)), ownership structure and banking regulations (Laeven and Levine (2009)), size (Demsetz and Strahan (1997)), and franchise value (Demsetz et al. (1997)) on risk-taking by banks. Our paper contributes to this literature by examining how the strength and independence of the risk management function affects risk-taking.

Finally, our paper also contributes to the small but growing literature on the corporate governance of financial institutions. Macey and O'Hara (2003) argue that the fiduciary duties of bank officers and directors should be expanded beyond shareholders to include creditors. Adams and Mehran (2003) highlight key differences in internal governance structures and ownership structure between bank holding companies and non-financial firms. Examining 306 global financial institutions that were at the center of the financial crisis, Erkens et al. (2009) find that CEO turnover is more sensitive to shareholder losses among firms with greater board independence, larger institutional ownership, and smaller insider ownership. In contrast to papers on corporate governance that mainly focus on the bank's ability to take corrective action (e.g., firing the CEO) following poor performance, our focus is on internal risk controls that can restrain risk-taking behavior ex ante.

The rest of the paper is organized as follows. We outline our key hypotheses in Section 
1. We describe our data sources and construction of variables in Section 2, and provide descriptive statistics and preliminary results in Section 3. Our main empirical results are presented in Section 4. Section 5 concludes the paper.

\section{Hypotheses}

The key hypothesis which we aim to test is that banking institutions with strong and independent risk management functions have lower enterprise-wide risk, all else equal. Our hypothesis recognizes that strong internal risk controls are necessary to rein in the risktaking tendencies of bank executives. The following paragraph from Acharya et al. (2009) summarizes the risk-taking tendencies that arise within modern-day financial institutions, and why these cannot be checked through traditional monitoring by their debtholders, supervisory action of regulators, or external market discipline:

"Large, complex financial institutions are highly levered entities with over 90 percent leverage, many with access to explicit deposit insurance protection and most with implicit too big to fail guarantees. Together, these features have created several important problems. First, they have induced excessive leverage- and risk-taking tendencies. Second, the presence of implicit or explicit government guarantees - often underpriced and at best mispriced - has blunted the instrument of debt monitoring that would otherwise impose market discipline on risk taking by these firms. Third, the size of these institutions has shielded them from the disciplinary forces of the otherwise vibrant market for takeovers and shareholder activism. Finally, their ever-increasing complexity has diminished the power of governance from existing shareholders and non-executive board members. Unlike in industrial firms, it has become increasingly difficult for infrequently meeting boards to fully grasp the swiftness and forms by which risk profiles of these institutions can be altered by traders and security desks. "

One mechanism that can check the risk-taking tendencies of bank executives and traders is the presence of a strong and independent risk management function (see Kashyap et al. (2008), Landier et al. (2008)). Note that for risks to be successfully managed, they must first be identified and measured. This is particularly challenging for banking institutions given the multitude of risks that they are exposed to. Apart from credit risk, banks are also exposed to interest rate risk and liquidity risk given that they finance illiquid assets with liquid liabilities such as deposits (Diamond (1984), Diamond and Rajan (2001)). Trading and underwriting activities of their subsidiaries not only increase the risk exposures of individual banks, but also increase the risk of broad systemic failure, because the failure of one segment of a large institution (e.g., the derivatives desk at AIG) can trigger a broader 
systemic failure through depositor panics, counter-party failures, and systemic liquidity shortages (Diamond and Rajan (2005)).

Past research has highlighted that organizational structure influences the effectiveness of information sharing between business segments and the top management (Stein (2002), Liberti (2005)). Therefore, the organizational structure of the risk management function is likely to be important in determining how effectively qualitative and quantitative information on risk is shared between the top management and the individual business segments. Accordingly, we collect information on how the risk management function is organized at each bank holding company in our sample. However, measuring risk by itself may not be enough to restrain bank executives and traders, whose bonuses depend on the risks that they take. ${ }^{10}$ As Kashyap et al. (2008) note (also see Stulz (2008)),

\footnotetext{
“... high powered pay-for-performance schemes create an incentive to exploit deficiencies in internal measurement systems. . . this is not to say that risk managers in a bank are unaware of such incentives. However, they may be unable to fully control them."
}

Therefore, it is important that the risk management function be strong and independent. Accordingly, we collect information on not just whether a $\mathrm{BHC}$ has a designated officer tasked with managing enterprise-wide risk, but also how important such an official is within the organization.

In our empirical analysis, we test our hypothesis against the null hypothesis that internal risk controls do not have any meaningful effect on enterprise-wide risk. This could be because even the most sophisticated organizational structure may not be able to grasp the swiftness with which traders and security desks can alter the risk profile of the BHC. Importantly, the compensation packages of traders may be so convex that they cannot be restrained by internal risk controls (Landier et al. (2008)).

We also recognize that the causation between the strength of the risk management function and enterprise-wide risk can run in both directions; i.e., BHC risk characteristics might determine the choice of the risk management function, and the risk management function in turn affects risk. There are two possible ways in which risk characteristics may affect the organizational structure of the risk management function.

It is possible that BHCs exposed to greater risk choose stronger risk management systems. We refer to this as the endogenous choice hypothesis. This hypothesis follows from theories of hedging, which suggest that firms that are more likely to experience financial

\footnotetext{
${ }^{10}$ The inability of risk managers to restrain bank executives is highlighted by the experience of David Andrukonis, a risk manager at Freddie Mac, who tried to alert his senior management to the risks in subprime and Alt-A loans, but was unable to restrain them (see Calomiris (2008)).
} 
distress should also be more aggressive in managing their risks (Smith and Stulz (1985), Froot et al. (1993)). Consistent with hedging theories, Purnanandam (2007) shows that banks that face a higher probability of financial distress manage their interest rate risk more aggressively, both by using derivatives and by adopting conservative asset-liability management policies.

Alternatively, it is possible that the underlying risk culture of the BHC determines both the choice of the risk and the strength of the risk management system; i.e., conservative BHCs take lower risks and put in place stronger risk management systems, while aggressive BHCs take higher risks and also have weaker internal risk controls. We refer to this as the risk culture hypothesis.

The above discussion highlights the need for an empirical methodology that can account for the dynamically endogenous relationship between a BHC's risk and its risk management function.

\section{Sample Collection and Construction of Variables}

\subsection{Data Sources}

Our data comes from several sources. From the Edgar system, we hand-collect data on the organization structure of the risk management function at BHCs from the annual 10$\mathrm{K}$ statements and proxy statements filed by the BHCs with the Securities and Exchange Commission (SEC). Whenever the data is not available from these documents we use the BHCs' annual reports. We use this information to create a unique Risk Management Index (RMI) that measures the organizational strength and independence of the risk management function at the given BHC in each year. Given the effort involved in hand-collecting and validating the information for each BHC, we restrict ourselves to the time period 1999-2007, and to the 100 largest $\mathrm{BHCs}$, in terms of the book value of their total assets at the end of 2007. Although there were over 5,000 BHCs at the end of 2007, the top 100 BHCs account for close to $92 \%$ of the total assets of the banking system. Because only publicly listed BHCs file 10-K statements with the SEC, our sample reduces to 74 BHCs, that accounted for $78 \%$ of the total assets of the banking system in 2007. Overall, we are able to construct the RMI for 74 BHCs over the time period 1999-2007. We list the names of these BHCs in Appendix A.

We obtain consolidated financial information of BHCs from the FR Y-9C reports that they file with the Federal Reserve System. Apart from information on the consolidated balance sheet and income statement, the FR Y-9C reports also provide us a detailed break- 
up of the BHC's loan portfolio, security holdings, regulatory risk capital, and off-balance sheet activities such as usage of derivatives. The financial information is presented on a calendar year basis.

We obtain data on stock returns from CRSP, and use these to compute our measure of a BHC's Aggregate Risk, which is defined as the standard deviation of the BHC's weekly excess return (i.e., weekly return on the BHC's stock less the weekly return on the S\&P500) over the calendar year. We also use the CRSP data to compute a measure of Tail Risk proposed by Acharya et al. (2009), which they refer to as the marginal expected shortfall (MES). In a given year, the MES is defined as the negative of the average return on the BHC's stock during the $5 \%$ worst days for the S\&P500. Thus, it is a measure of the BHC's tail $\beta .{ }^{11}$ We obtain implied volatilities estimated from option prices from the OptionMetrics database, and use these to compute our measure of a BHC's Downside Risk, which is defined as the mean implied volatility estimated using put options written on the BHC's stock.

We obtain data on CEO compensation from the Execucomp database, and use these to compute the sensitivity of the CEO's compensation to stock price (CEO's Delta) and stock return volatility (CEO's Vega). We obtain data on institutional ownership from the 13-F forms filed by each institutional investor with the SEC, and the Gompers et al. (2003) G-Index from the IRRC database.

\subsection{The Risk Management Index}

We hand-collect information on various aspects of the organization structure of the risk management function at each $\mathrm{BHC}$, and use this information to create a Risk Management Index to measure the strength and independence of the organizational strength of the risk management function. We obtain the RMI for each BHC and each year in our sample. In total we have 673 BHC-year observations for the RMI over the period 1999-2007.

Our first set of variables are aimed at capturing whether the BHC has a designated officer charged exclusively with managing enterprise-wide risk across all business segments, and how important this official is within the organization. Specifically, we create the following variables: CRO Present, which is a dummy variable that identifies if the BHC has a designated Chief Risk Officer (CRO) or not; CRO Executive, a dummy variable that identifies if the CRO is an executive officer of the $\mathrm{BHC}$ or not; CRO-Top5, a dummy variable that identifies if the $\mathrm{CRO}$ is among the five highest paid executives at the BHC or not; and CRO Centrality, defined as the ratio of the CRO's total compensation to the CEO's total

\footnotetext{
${ }^{11}$ It may be argued that the tail $\beta$ captures only one factor, namely, return on the S\&P500. Alternatively, one could define MES as the negative of the average return on the BHC's stock during the $5 \%$ worst days for the stock (we thank Charles Calomiris for this suggestion).
} 
compensation. The idea behind CRO Centrality is to use the CRO's relative compensation to infer his/her relative power or importance within the organization. ${ }^{12}$

We must point out that reporting issues may cause the CRO Present variable to be biased downwards. In some of the smaller BHCs that are mainly oriented towards retail banking, the Chief Lending Officer or the Chief Credit Officer may be the official in charge of risk management. To ensure that we are not missing out on these alternative designations, we treat them on par with Chief Risk Officer while coding the CRO Present variable, although this may introduce noise into our definition. More seriously, however, it is possible that a BHC has a Chief Risk Officer (or a Chief Lending Officer or a Chief Credit Officer) but simply fails to report this in its $10-\mathrm{K}$ statement, proxy statement and annual report, because it is not required to report this information. This will clearly introduce a downward bias in the CRO Present variable. Indeed, as we discuss below, we find that a Chief Risk Officer (or an equivalent designation) is present only in a little over $60 \%$ of all the BHC-year observations. Given that this variable may be noisy because of reporting issues, we do not include CRO Present in our RMI measure. However, to test the robustness of our results, we create an alternative RMI measure that also includes CRO Present.

Note that the CRO Executive variable is likely to be less noisy than CRO Present because firms are more likely to report the names and designations of their executive officers in their proxy statements or annual reports. Also, the CRO-Top5 variable does not suffer from reporting issues because all firms are required to reveal the names and designations of their five highest paid executives in their $10-\mathrm{k}$ statements.

Reporting issues also complicate the definition of the CRO Centrality variable, because publicly-listed firms are only required to disclose the compensation packages of their five highest paid executives. Thus, we have information on the CRO's compensation only when he/ she is among the five highest paid executives. We overcome this difficulty as follows: When the $\mathrm{BHC}$ has a $\mathrm{CRO}$ (or an equivalent designation) who does not figure among the five highest paid executives, we calculate CRO Centrality based on the compensation of the fifth highest-paid executive, and subtract a percentage point from the resultant ratio; i.e., we implicitly set the CRO's compensation just below that of the fifth-highest paid executive. In case of BHCs that do not report having a CRO, we define CRO Centrality based on the total compensation of the Chief Financial Officer if that is available (which happens only if the CFO is among the five highest paid executives) ${ }^{13}$ if $\mathrm{CFO}$ compensation is not available, then we compute CRO Centrality based on the compensation of the fifth highest-paid executive, and subtract a percentage point from the resultant ratio. To the

\footnotetext{
${ }^{12}$ Keys, Mukherjee, Seru, and Vig (2009) use a similar measure to capture the relative power of the CFO within the bank.

${ }^{13}$ The reasoning behind using the CFO's compensation is that, in BHCs that either do not have or do not report having a $\mathrm{CRO}$, the $\mathrm{CFO}$ is most likely in charge of risk management.
} 
extent that the CRO's true compensation is much lower, these methods only bias against us, and should make it more difficult for us to find a negative relationship between RMI and risk. Another alternative is to code $C R O$ Centrality $=0$ when the $\mathrm{BHC}$ does not have or does not report to have a designated CRO. Not surprisingly, in unreported tests, we find that our results become stronger when we use this more stringent definition of $C R O$ Centrality.

Our next set of variables are intended to capture the quality of risk oversight provided by the BHC's board of directors. In this regard, we examine the characteristics of the board committee designated with overseeing and managing risk, which is usually either the Risk Management Committee or the Audit and Risk Management Committee. We do not distinguish between whether the board risk committee exclusively deals with risk management or combines it with another function such as auditing. Risk Committee Experience is a dummy variable that identifies whether at least one of the grey or independent directors serving on the board's risk committee has banking experience. ${ }^{14}$ We also measure the banking and financial industry experience of all the grey and independent directors serving on the BHC's board of directors. We define the dummy variable Experienced Board to take the value of 1 if the BHC's board has a larger proportion of its independent and grey directors with banking or financial industry experience compared to the average board across all BHCs each year. We measure the activity of the board risk committee in terms of the frequency with which it meets during the year. The dummy variable Active Risk Committee then identifies if the BHC's board risk committee met more frequently during the year compared to the average board risk committee across all BHCs.

To capture how well risk information is shared between business units and the board, we define the dummy variable Reports to Board to identify whether the key management-level risk committee (usually called the "Asset and Liability Committee") reports directly to the BHC's board of directors, instead of to the CEO. Here again, we want to point out that the variable Reports to Board may suffer from reporting biases, because in slightly over $25 \%$ of the BHC-year observations, we find no information on the reporting channel of the management-level risk committee. In such cases, we set Reports to Board equal to zero; i.e., we assume that the key management-level risk committee reports to the CEO instead of to the Board. Due to these possible reporting biases, we do not include the Reports to Board variable our RMI. However, it is included in our alternative RMI measure, Alt. RMI, which we create to test the robustness of our results.

We obtain the $R M I$ by taking the first principal component of the following five risk management variables: CRO Executive, CRO-Top5, CRO Centrality, Risk Committee Ex-

\footnotetext{
${ }^{14} \mathrm{As}$ is standard in the Corporate Governance literature, we use the term "grey" directors for directors who are not insiders but are also not independent, because they have connections to the firm.
} 
perience, and Active Board Risk Committee over the time period 1999-2007. Principal component analysis effectively performs a singular value decomposition of the correlation matrix of risk management categories measured over time. The single factor selected in this study is the eigenvector in the decomposition with the highest eigenvalue. The main advantage of using principal component analysis is that we do not have to subjectively eliminate any categories, or make subjective judgements regarding the relative importance of these categories.

We also create two alternative measures, Alt. RMI and Alt. RMI 2, to test for the robustness of our results. We obtain Alt. RMI by taking the first principal component of the following seven risk management variables: CRO Present, CRO Executive, CROTop5, CRO Centrality, Risk Committee Experience, Reports to Board and Active Board Risk Committee. We obtain Alt. RMI 2 by taking the first principal component of the following six risk management variables: CRO Executive, CRO-Top5, CRO Centrality, Risk Committee Experience, Active Risk Committee, and Experienced Board.

\section{Descriptive Statistics and Preliminary Results}

\subsection{Descriptive Statistics}

We present summary statistics of the key risk management variables and financial variables for the BHCs in our panel in Table I. The overall panel includes 100 BHCs and spans the time period 2000-08; each observation corresponds to a BHC-year combination. However, information on risk management characteristics and standard deviation of stock returns is only available for the 74 BHCs that are publicly listed.

\section{[Insert Table I here]}

The summary statistics on Downside Risk indicate that the mean implied volatility estimated from put options written on BHC stocks has a sample average of 0.397, and a median of 0.350 . The mean of 0.025 on Tail Risk indicates that the mean return on the average BHC stock on the $5 \%$ worst days for the S\&P500 during the year is $-2.5 \%$. The mean of 0.038 on Aggregate Risk indicates that the standard deviation of weekly excess return on the average BHC's stock during the year is $3.8 \%$. As can be seen, the average annual return on a BHC stock during our sample period is $4.6 \%$. However, this variable is highly variable: the $\mathrm{BHC}$ at the $25^{\text {th }}$ percentile cutoff had an annual return of $-12.1 \%$, while the BHC at the $75^{t h}$ percentile cutoff had an annual return of $21.5 \%$. 
The summary statistics on $R M I$ indicate that our index is not highly skewed, and does not suffer from the presence of outliers. The mean and median values of $R M I$ are 0.451 and 0.410 , respectively, and the standard deviation is modest in comparison to the mean.

Examining the descriptive statistics regarding the components of RMI, we find that a designated Chief Risk Officer (or an equivalent designation) was present in only $61.8 \%$ of the BHC-year observations in our sample. While this number may seem surprisingly low, it could arise because of the reporting issues we highlighted above in Section 2.2. Therefore, we choose not to include this measure in our $R M I$.

As can be seen from the summary statistics on CRO Executive and CRO Top5, the designated CRO had an executive rank in $51.9 \%$ of BHC-year observations, and was among the top five highly-paid executives in only $19.5 \%$ of BHC-year observations. As we explained in Section 2.2, these variables are less subject to reporting bias when compared with the $C R O$ Present variable. The summary statistics on the CRO Centrality variable indicate that, on average, the CRO's total compensation was $32.4 \%$ that of the CEO's total compensation.

The mean value of 0.232 on Risk Committee Experience indicates that, in around $77 \%$ of BHC-year observations, not even one of the grey or independent directors on the board's risk committee had any prior banking experience. As the summary statistics on the Freq. Meetings: Risk Committee variable indicate, the board risk committee meets 5.052 times each year on average, although a number of banks have risk committees that meet much more frequently, some even twice or more every quarter (the $75^{\text {th }}$ percentile cutoff for this variable is 8). We classify a BHC as having an Active Risk Committee during a given year if the frequency with which its board risk committee met during the year was higher than the average frequency across all BHCs during the year. By this classification, $46.2 \%$ of BHCs in our sample had active board risk committees.

We also examine the banking/ financial industry experience of all the grey or independent directors on the BHC's board of directors. As can be seen from the summary statistics on Frac. Experienced Directors, in the average BHC in our sample, only $22.5 \%$ of the noninside directors have prior banking or financial industry experience. We classify a BHC as having an Experienced Board if Frac. Experienced Directors for the BHC is higher than the average value across all BHCs during the year. By this definition, $48.2 \%$ of BHCs in our sample have boards with a high level of banking or financial industry experience. The mean of 0.518 on Report to Board indicates that the principal management-level risk committee reported directly to the board of directors (instead of the CEO) in $51.8 \%$ of BHC-year observations.

The size distribution of BHCs, in terms of the book value of their assets, is highly skewed. Total assets vary from $\$ 387$ million at the lower end to over $\$ 2$ trillion at the 
higher end. The median BHC had assets with book value of $\$ 12.4$ billion, while the average BHC had assets with book value of $\$ 86$ billion. Given the skewness of the size distribution we use the logarithm of the book value of assets, denoted Size, as a proxy for BHC size in all our empirical specifications.

On average, deposits constitute $66 \%$ of liabilities plus equity, and loans constitute $61 \%$ of the assets. In terms of the health of the loan portfolio, the average BHC has $0.7 \%$ of its assets in 'bad' or non-perfoming loans, i.e., non-accrual loans and loans that are 90 days past due and still accruing. As can be seen from the summary statistics on $U W$ Assets/Assets and Ins. Assets/Assets, subsidiaries engaged in underwriting or dealing securities, on average, constitute $1.3 \%$ of the total assets of the $\mathrm{BHC}$, while subsidiaries engaged in insurance, on average, constitute $0.8 \%$ of the total assets of the BHC.

As can be seen from the summary statistics on Deriv. Hedging/Assets and Deriv. Trading/Assets, there is a great deal of variation among BHCs in terms of their use of derivatives for hedging purposes, and their trading of derivatives. The median BHC uses derivatives for hedging that amount to only $3 \%$ of its assets, and does not hold any derivatives for trading purposes. However, there are a few BHCs that have very large exposures to derivatives, especially for purposes other than hedging.

In terms of governance characteristics, the average BHC had $46.8 \%$ of its shares held by institutional investors, and had a G-index of 9.62. We must note that there is a clear time-trend in these two variables, with the institutional ownership increasing through our sample period, and the G-index improving over the same period.

\subsection{Correlations Among Key Variables}

In Table II, we list the correlations among the key variables used in our analysis.

\section{[Insert Table II here]}

Panel A lists the pair-wise correlations between our risk measures, RMI and BHC financial characteristics. All three risk measures are negatively correlated with $R M I_{t-1}$, although the correlation is strongest for Downside Risk. All three risk measures are negatively correlated with the profitability measure, $R O A$, and with the Tier-1 capital ratio, which is consistent with the idea that profitable banks and well-capitalized banks take lower risks. The correlation between the risk measures and Bad Loans/Assets L $_{-1}$ is strongly positive, which indicates that BHCs with a high proportion of non-performing loans are more risky. On the other hand, the negative correlation between the risk measures and (Non-int 
income/Income $)_{t-1}$ indicates that $\mathrm{BHCs}$ with more diversified sources of income are less risky.

Consistent with the idea that, in the presence of deposit insurance, institutional investors have incentives to take on higher risks (Saunders et al. (1990)), we find a strong positive correlation between the risk measures and Inst. Ownership. The correlation between the risk measures and the CEO's Delta is also positive, which is surprising because greater exposure to the bank's equity should make the CEO more risk averse. Not surprisingly, we find a positive correlation between CEO's Vega and the risk measures.

We must, however, caution against over-interpreting the results from Panel A because these are simple pair-wise correlations that do not take into account other BHC characteristics.

Panel B lists the correlations between our risk measures and the various components of the RMI. As can be seen, the correlations between our risk measures and the index components are mostly negative. The negative correlations are the strongest in case of Downside Risk. It should also be noted that, among all the RMI components, CRO Centrality has the strongest negative correlation with Tail Risk and Aggregate Risk, and has the second strongest negative correlation with Downside Risk.

We now proceed to our multivariate analysis where we examine the relationship between $\mathrm{BHC}$ risk measures and $\mathrm{RMI}$ after controlling for important $\mathrm{BHC}$ characteristics.

\section{Empirical Results}

\subsection{RMI and Performance during Crisis Years}

In motivating our paper, we cited the Senior Supervisors Group (2008) report which suggested that institutions with stronger risk management functions fared better in the early months of the crisis. So it is natural to begin our analysis by asking whether BHCs that had stronger internal risk controls in place before the onset of the financial crisis were more judicious in their exposure to risky investments and fared better during the crisis years, 2007 and 2008. Accordingly, we begin by investigating the univariate relationship between the BHC's RMI in the years prior to the onset of the financial crisis and the enterprise-wide risk during the crisis years. For each BHC, we calculate the average value of its RMI over the period 2003-2006 as a measure of the strength of its risk management function in the years before the onset of the financial crisis. We then plot the relationship between the actual and fitted values of the BHCs' average downside risk during the crisis years (2007-08) 
versus their pre-crisis RMI in Figure $1 .{ }^{15}$

\section{[Insert Figure 1 here]}

This univariate test reveals a clear and statistically significant negative relationship between pre-crisis RMI and downside risk during the financial crisis years, providing the first preliminary indication that BHCs with stronger risk controls in place before the onset of the financial crisis had lower enterprise-wide risk during the crisis years. To investigate this further, we examine how downside risk varied with pre-crisis CRO Centrality, which we obtain by taking the average of CRO Centrality over the period 2003-2006. We choose CRO centrality for this investigation because the principal component analysis revealed this to be a key constituent of the RMI. We then plot the relationship between the actual and fitted values of the BHCs' average downside risk during the crisis years (2007-2008) versus their pre-crisis RMI in Figure 2. ${ }^{16}$

\section{[Insert Figure 2 here]}

Our findings in Figure 2 are consistent with what we found in Figure 1: BHCs with powerful CROs in the years before the onset of the financial crisis had lower downside risk during the crisis years.

Following the univariate tests, we proceed to we estimate cross-sectional regressions only for the crisis years, 2007 and 2008, that are of the following form:

$$
Y_{j, t}=\alpha+\beta * \mathrm{RMI}_{j, 2006}+\gamma * X_{j, 2006}+\text { Year FE }
$$

In the above equation, subscript ' $\mathrm{j}$ ' denotes the $\mathrm{BHC}$ and ' $\mathrm{t}$ ' denotes the year. Our main independent variable of interest is the BHC's risk management index in $2006, R M I_{j, 2006}$. We choose RMI in 2006 as the independent variable because institutions with strong risk controls would have identified risks and started taking corrective actions as early as in 2006, when it was easier to offload holdings of mortgage-backed securities and CDOs, and was relatively cheaper to hedge risks. We also control for BHC characteristics at the end of calendar year 2006. ${ }^{17}$ The results of our estimation are presented in Table III. We

\footnotetext{
${ }^{15}$ The fitted values are the predicted values obtained from an OLS regression of BHCs' average downside risk during the crisis years on a constant and the pre-crisis RMI. The t-statistic of the coefficient estimate is -2.25. We obtain similar results when we use alternative measures of risk (Tail Risk or Aggregate Risk), or when we use just the 2006 RMI instead of the average RMI across 2003-2006.

${ }^{16}$ The fitted values are the predicted values obtained from an OLS regression of BHCs' average downside risk during the crisis years on a constant and the pre-crisis CRO Centrality. The t-statistic of the coefficient estimate is -2.88 .

${ }^{17}$ We obtain qualitatively similar results when we use lagged BHC characteristics, instead of 2006 characteristics, as control variables.
} 
include 2007 and 2008 year dummies in all specifications. The standard errors are robust to heteroskedasticity and are clustered at the BHC level.

\section{[Insert Table III here]}

In Column (1), we examine whether BHCs with stronger risk controls in 2006 had lower exposure to mortgage-backed securities during the crisis years, 2007 and 2008. The dependent variable, Private $M B S$, denotes the total value of private-label mortgage-backed securities (in $\$$ million) held in both trading and investment portfolios; i.e., we exclude mortgage-backed securities that are either issued or guaranteed by government sponsored enterprises (GSEs), because these are less risky. We are interested in exposure to mortgagebacked securities because the financial crisis was itself triggered by a housing crisis in the U.S., and there was considerable uncertainty regarding the true values of these securities during 2007 and 2008. The coefficient on $R M I_{2006}$ in Column (1) is negative, suggesting that BHCs with stronger risk controls in place before the crisis had lower exposure to private-label mortgage-backed securities during the crisis years.

The dependent variable in Column (2) is Risky Trading Assets, which is the book value of assets in the BHC's trading portfolio, after excluding relatively safe securities such as U.S. Treasury securities, U.S. government obligations, securities issued by states and political subdivisions in the U.S, and securities issued or guaranteed by GSEs. The negative and significant coefficient on $R M I_{2006}$ in Column (2) indicates that BHCs with stronger risk controls in place before the crisis hit had lower exposure to risky trading assets during the crisis years.

In Column (3), we examine the off-balance sheet derivative trading activities of BHCs during the crisis years. The dependent variable is Deriv. Trading, which is the gross notional amount (in $\$$ billion) of derivative contracts held for trading. The negative and significant coefficient on $R M I_{2006}$ indicates that BHCs with stronger risk controls also had lower exposure to off-balance sheet derivative trading activity during the crisis years.

The dependent variable in Column (4) is Bad Loans/Assets, where Bad Loans include loans past due 90 days or more and non-accrual loans. Thus, Bad Loans/Assets is a measure of the health of the BHC's loan portfolio. The negative coefficient on $R M I_{2006}$ indicates that BHCs with stronger risk controls before the crisis hit had relatively healthier loan portfolios during the crisis years. The dependent variable in Column (5) is ROA, which is the ratio of income before extraordinary items to total assets. As the insignificant coefficient on $R M I_{2006}$ indicates, we fail to find any evidence that BHCs with high RMI in 2006 were more profitable during the crisis years. 
In Column (6), we examine whether BHCs with strong internal risk controls experienced better stock return performance during the crisis years. The dependent variable in this regression is the annual return on the BHC's stock. As can be seen, while the coefficient on $R M I_{2006}$ is positive, it is not statistically significant.

In Columns (7) and (8), we examine two measures of enterprise-wide risk. The dependent variable in Column (7) is Aggregate Risk, which is estimated as the standard deviation of weekly excess return on the BHC's stock during the calendar year. The dependent variable in Column (8) is Downside Risk, which is the mean implied volatility estimated using put options written on the BHC's stock. Accordingly, the sample for the regression in Column (8) is smaller because it only includes those BHCs with tradable put options. The negative and significant coefficient on $R M I_{2006}$ in Column (8) indicates that BHCs with strong internal risk controls had lower downside risk during the crisis years. As opposed to this, the coefficient on $R M I_{2006}$ in Column (7) while negative is not statistically significant.

Overall, the results in Table III are broadly supportive of the argument in the Senior Supervisors Group (2008) report that BHCs with strong and independent risk management functions in place before the onset of the financial crisis, were more judicious in their risk exposures, and fared better during the crisis years. We must reiterate that the regressions in Table III are simple cross-sectional regressions that are confined to the crisis years, and do not control for unobserved heterogeneities across BHCs. However, these results do indicate that internal risk controls could have an impact on the risk taking behavior of BHCs. It is natural to ask whether the results hold more generally even during non-crisis years, and whether they are robust to controlling for unobserved heterogeneity across BHCs. To address these questions, we next proceed to panel regressions where we examine a longer time span, and are able to control for unobserved heterogeneity using BHC fixed effects.

\subsection{Impact of RMI on Enterprise-wide Risk}

In this section, we examine whether BHCs that had strong and independent risk management functions in place had lower aggregate risk and lower downside risk, after controlling for the underlying risk of the BHC's business activities. Accordingly, we estimate panel regressions that are variants of the following form:

$$
\operatorname{Risk}_{j, t}=\alpha+\beta * \mathrm{RMI}_{j, t-1}+\gamma * X_{j, t-1}+\mathrm{BHC} \mathrm{FE}+\text { Year FE }
$$

We estimate this regression on a panel that has one observation for each BHC-year combination, includes the BHCs listed in Appendix A, and spans the time period 20002008. In the above equation, subscript ' $\mathrm{j}$ ' denotes the BHC and ' $\mathrm{t}$ ' denotes the year. 
The dependent variable is a measure of the BHC's enterprise-wide risk, while the main independent variable is its lagged RMI. We use three different measures of risk: Downside Risk, Tail Risk and Aggregate Risk. We include year fixed effects, as well as BHC fixed effects to control for any time-invariant unobserved BHC characteristics that might affect risk; e.g., the BHC's risk culture. The results of our estimation are presented in Table IV. In all specifications, the standard errors are robust to heterogeneity and are clustered at the individual BHC level.

We control these regressions for important BHC financial characteristics from the previous year $\left(X_{j, t-1}\right)$. The definitions of all the variables we use in our analysis are listed in Appendix B. We control for the BHC's size using the natural logarithm of the book value of total assets (Size), for profitability using the ratio of income before extraordinary items to assets (ROA), and for past performance using its Annual Stock Return. We control for balance sheet composition using the ratios Deposits/Assets, Tier-1 Cap/Assets and Loans/Assets, and for the quality of loan portfolio using the ratio Bad Loans/Assets, where Bad Loans include non-accrual loans and loans past due 90 days or more. We proxy for the BHC's reliance on off-balance sheet activity using the ratio Non-Int. Income/Income (see Boyd and Gertler (1994)).

The identifying assumption behind the panel regression (2) is that $R M I_{j, t-1}$ is exogenous, after conditioning on all the control variables $\left(X_{j, t-1}\right)$ and BHC fixed effects. This assumption may not be valid if some time-varying omitted variable affects both the RMI and the BHC's risk in the subsequent year, or if the relationship between risk and RMI is dynamically endogeneous; i.e., if causation between risk and RMI runs in both directions such that past values of risk may affect both current risk and RMI. As far as possible, we attempt to mitigate the omitted variable bias by controlling for other BHC characteristics that are likely to be related to BHC Risk. These include the extent of the BHC's reliance on underwriting and insurance activities (UW Assets/Assets and Ins. Assets/Assets), institutional characteristics such as Inst. Ownership and quality of governance (G-Index), CEO compensation characteristics (CEO's Delta and CEO's Vega), and the BHC's reliance on derivatives for hedging (Deriv Hedging/Assets) and trading purposes (Deriv Trading/Assets). In Section 4.4, we estimate a dynamic panel GMM estimator to directly control for the dynamic endogeneity problem.

\section{Impact on Downside Risk}

In Panel A, we report the results of regressions with Downside Risk, which denotes the mean implied volatility estimated from put options written on the BHC's stock, as the dependent variable. Accordingly, the sample for this regression only includes BHCs that have tradable 
put options which we can use to estimate implied volatility.

\section{[Insert Table IV here]}

As can be seen, the coefficient on $R M I_{t-1}$ in Column (1) is negative and statistically significant at the $5 \%$ level, which indicates that BHCs that had strong internal risk controls in place in the previous year have lower downside risk in the current year. In terms of economic significance, the coefficient of -0.325 on $R M I_{j, t-1}$ indicates that a one standard deviation increase in RMI is associated with a decrease of 0.067 in downside risk, which is equivalent to a 0.39 standard deviation decrease in downside risk.

In terms of the coefficients on the control variables, we fail to detect any relationship between BHC size and downside risk. The negative coefficient on Return $n_{t-1}$ indicates that well-performing BHCs have lower downside risk; in a similar vein, the coefficient on $R O A_{t-1}$ is negative, but is not statistically significant. The coefficient on (Deposits/Assets) $t_{-1}$ is positive and significant, which is consistent with the argument that moral hazard induced by deposit insurance causes BHCs to take higher risks. One variable that has a strong positive relationship with downside risk is (Bad Loans/Assets) ${ }_{t-1}$, which indicates that implied volatilities are higher for BHCs that have a larger fraction of non-performing loans.

Even though we include year fixed effects, and BHC fixed effects to control for the effect of time-invariant omitted variables, it is possible that the negative association between Downside Risk and $R M I_{t-1}$ in Column (1) is being driven by some time-varying omitted variable that affects both the RMI and the BHC's risk in the subsequent year. In the remaining specifications in Panel $\mathrm{A}$, we attempt to rule out this explanation by explicitly controlling for other $\mathrm{BHC}$ characteristics that the existing literature has shown to be related to risk.

Past research has highlighted that, in the presence of deposit insurance, diversified stockholders such as institutional investors may have incentives to take on higher risk (Saunders et al. (1990), Demsetz et al. (1997), Laeven and Levine (2009)). Therefore, in Column (2), we include Inst. Ownership $p_{-1}$, the fraction of stock owned by institutional investors, as an additional control. We control for the BHC's overall corporate governance using the lagged value of its G-Index. We also use the ratios UW Assets/Assets and Ins. Assets/Assets to proxy for the BHC's reliance on underwriting and insurance activity, respectively, because these are likely to be related to enterprise-wide risk. As can be seen, the coefficient on Inst. Ownership $_{t-1}$ is indeed positive and significant, while there is no relationship between risk and the G-index. The coefficients on (UW Assets/Assets) ${ }_{t-1}$ and (Ins. Assets/Assets) ${ }_{t-1}$ are negative and significant, suggesting that BHCs with a more diversified business portfolio have lower downside risk. More importantly, the coefficient on $R M I_{t-1}$ not only remains 
negative and significant, but actually becomes larger in magnitude when compared with Column (1).

In Column (3), we attempt to proxy for the time-varying omitted risk characteristics by including two new ratios, Deriv Hedging/Assets ${ }_{t-1}$ and Deriv Trading/Assets ${ }_{t-1}$, which measure the BHC's reliance on derivatives for hedging purposes and trading, respectively. The idea here is that if a BHC changes its risk exposure or the way it manages risk, it should be captured by these two additional ratios. As can be seen, the coefficient on Deriv Hedging/Assets ${ }_{t-1}$ is negative and significant, which indicates that BHCs that rely more on derivatives for hedging have lower downside risk. More importantly, the coefficient on $R M I_{t-1}$ continues to be negative and significant.

It is commonly argued in the popular press that bank CEO compensation packages have contributed to higher risk taking. ${ }^{18}$ In Column (4), we repeat our regression after controlling for the following characteristics of CEO compensation: CEO Delta, which is the sensitivity of the CEO's compensation to stock price; and CEO Vega, which is the sensitivity of compensation to stock return volatility (see Core and Guay (1999)). This lowers our sample size significantly, because the ExecuComp database, from which we obtain information on CEO compensation, does not cover all the BHCs in our sample. As can be seen, while the coefficient on CEO Delta $a_{t-1}$ is negative, suggesting that a large equity component in the CEO's compensation is associated with lower risk, it is not statistically significant. More importantly, the inclusion of CEO compensation characteristics only strengthens the negative coefficient on $R M I_{t-1}$.

In Column (5), we repeat our estimation in Column (4) with an alternative index of the strength of risk management, Alt. $R M I_{t-1}$. The negative and significant on Alt. $R M I_{t-1}$ highlights that our result is robust to our definition of RMI. In unreported tests, we find similar results when we use another alternative measure, Alt. RMI 2.

Overall, the results in all the columns of Panel A indicate that BHCs with strong internal risk controls in place in the previous year have lower downside risk in the current year.

We estimate several additional specifications which we do not report here to conserve space (these results are available upon request). Because past research by Calomiris and Nissim (2007) shows that BHC valuations depend crucially on the composition of loans and deposits, we explicitly control for these in our regressions. Specifically, we replace the Loans/Assets variable with the ratios Real Estate Loans/Assets, CEI Loans/Assets, Con-

\footnotetext{
${ }^{18}$ However, the findings in the empirical literature in this regard are somewhat mixed. Examining bank behavior during the period 1992-2002, Mehran and Rosenberg (2007) find that equity volatility and asset volatility of banks increase as their CEO stock option holdings increase. However, examining the behavior of banks during the crisis period, Fahlenbrach and Stulz (2009) find that option compensation did not have an adverse impact on bank performance.
} 
sumer Loans/Assets, Agri. Loans/Assets and Other Loans/Assets to control for the BHC's exposure to loans secured by real estate, commercial and industrial loans, consumer loans, agricultural loans and other loans, respectively. We also control for the concentration of the BHC's loan portfolio among these five segments using the variable Loan Concentration, which is defined as the sum of squares of shares of each loan segment in the overall loan portfolio. Further, we replace the Deposits/Assets variable with the ratios Core Deposits/Assets and Non-core Deposits/Assets to distinguish between "core" deposits (which include deposits held in domestic offices of subsidiaries of the BHC, excluding all time deposits of over $\$ 100,000$ and any brokered deposits) and all other "non-core" deposits. The coefficient on $R M I_{t-1}$ continues to be negative and significant even after the inclusion of all these additional controls.

\section{Impact on Tail Risk}

In Panel B, we present the results of regressions aimed at understanding how the BHC's tail risk varies with its RMI. We do this by using a measure of tail risk proposed by Acharya et al. (2009), MES, as our dependent variable. Recall that, in any calendar year, the $M E S$ is defined as the negative of the average return on the BHC's stock over the $5 \%$ worst days for the S\&P500. The empirical specification and control variables are exactly the same as in Panel A. The negative and significant coefficient on $R M I_{j, t-1}$ in Column (1) indicates that BHCs that had strong and independent risk management functions in place in the previous year have lower tail risk in the current year. In terms of economic significance, a one standard deviation increase in $R M I_{j, t-1}$ is associated with a decrease of 0.015 in tail risk, which is equivalent to a 0.62 standard deviation decrease in tail risk.

The coefficients on the control variables are somewhat different from those in Panel A. In particular, the coefficient on Size $_{t-1}$ is negative, which indicates that larger BHCs were exposed to greater tail risk. On the other hand, the coefficient on (Bad Loans/Assets) $)_{t-1}$ is insignificant, which means that tail risk is not related to the fraction of non-performing loans on the BHC's balance sheet. The tail risk also does not seem to depend on institutional ownership or derivative usage for hedging, factors which were significantly related to downside risk.

As in Panel A, the negative association between $R M I j, t-1$ and tail risk is robust to controlling for institutional ownership, governance and derivative usage. However, the negative coefficient on $R M I j, t-1$ becomes statistically insignificant at conventional levels of significance (the p-value is 0.19 ) once we condition on the CEO's compensation characteristics. As can be seen from Column (4), there is a strong negative association between tail risk and CEO's Delta; i.e., banks whose CEO's have a high equity component in their com- 
pensation package have lower tail risk. When we repeat our estimation with an alternative index of the strength of risk management, Alt. $R M I_{t-1}$, we find that the negative association between RMI and tail risk is also robust to controlling for the CEO's compensation characteristics (see Column (5)).

As we noted earlier in footnote 11, it could be argued that the MES measure which we use as a proxy for Tail Risk, captures the impact of only one risk factor, namely, return on the S\&P500. Alternatively, one could define MES as the negative of the average return on the BHC's stock during the $5 \%$ worst days for the stock (instead of over the $5 \%$ worst days for the S\&P500). In unreported tests, we replicate the analysis in Panel B with this alternative measure of Tail Risk as the dependent variable, and obtain qualitatively similar results.

\section{Impact on Aggregate Risk}

In Panel $\mathrm{C}$, we present the results of regressions aimed at understanding how the BHC's aggregate risk varies with its RMI. The dependent variable in these regressions is Std. Dev. Excess Return. The empirical specification and control variables are exactly the same as in Panel A. The negative and significant coefficient on $R M I_{j, t-1}$ in Column (1) indicates that BHCs that had strong internal risk controls in place in the previous year have lower aggregate risk in the current year.

The coefficients on the control variables are similar to those in Panel A. There is no relationship between size and aggregate risk, while well-performing BHCs have lower aggregate risk (negative and significant coefficients on $R O A_{t-1}$ and Return $n_{t-1}$ ). Although the coefficient on (Bad Loans/Assets) ${ }_{t-1}$ is positive, it is not statistically significant in all specifications. The positive coefficient on Inst. Ownership suggests that BHCs with high institutional ownership have more volatile stock returns. The main difference compared to the earlier panels is the negative and significant coefficient on CEO Vega $a_{t-1}$, which suggests that banks whose CEO compensation is highly sensitive to stock volatility have lower aggregate risk.

The negative association between $R M I_{t-1}$ and Aggregate Risk $k_{t}$ is robust to controlling for institutional ownership, CEO's compensation characteristics, and the BHC's G-Index. The negative association is also robust to alternative definitions of the index (Column (5). Overall, the findings in Panel C indicate that BHCs with strong internal risk controls in place have lower aggregate risk. In terms of economic significance, the coefficient of -0.071 on $R M I_{t-1}$ in Column (4) indicates that a one standard deviation increase in RMI is associated with a decrease of 0.015 in aggregate risk, which is equivalent to a 0.6 standard deviation decrease in aggregate risk. 


\subsection{How Does the Impact of RMI on Risk Vary with BHC Characteris- tics?}

In our next set of tests, we interact the RMI variable with key BHC characteristics, such as size and profitability, to understand how the impact of RMI on risk varies with these BHC characteristics. The empirical specification and control variables we employ are exactly the same as in Column (1) of Table IV. However, to conserve space, we do not report the coefficients on control variables all over again. We also restrict our analysis to downside risk and aggregate risk only. The results of our estimation are presented in Table V.

\section{[Insert Table V here]}

In Columns (1) and (2), we examine how the effect of RMI on downside risk and aggregate risk varies with the size of the BHC. The idea is to see if a strong and independent risk management function matters more in large BHCs that are more likely to have multiple subsidiaries and multiple business segments. Given the highly skewed size distribution of BHCs that we highlighted in Table I, we define the dummy variable Large BHC to identify, in each year, the BHCs that are in the top decile in terms of their book value of assets. We then estimate the panel regression (2) after including Large $B H C_{t-1}$ and $\operatorname{Large}_{B H C_{t-1}}{ }^{R} R I_{t-1}$ as additional regressors. The negative and significant coefficients on $\operatorname{Large}_{B H C_{t-1}} R M_{t-1}$ in Columns (1) and (2) indicate that the effect of RMI in lowering downside risk and aggregate risk is stronger in large BHCs.

In Columns (3) and (4), we examine how the impact of RMI varies with the profitability of the BHC. We define the dummy variable Low ROA BHC to identify, in each year, BHCs that are in the lowest quartile in terms of their $R O A$. The positive and significant coefficient on Low $R O A B H C_{t-1} * R M I_{t-1}$ in Column (3) indicates that the effect of RMI in lowering downside risk is weaker in BHCs with low profitability. We do not detect a similar effect with respect to aggregate risk, as the coefficient on the interaction term in Column (4) is not statistically significant.

In Columns (5) and (6), we examine how the impact of RMI varies with the BHC's reliance on deposits to fund itself. There are two possible ways in which the effect might vary. On the one hand, BHCs that have a low deposits to assets ratio tend to be those with a presence in a wide variety of financial activities apart from traditional banking, such as asset management, underwriting, and insurance. Hence, the effect of RMI in lowering risk should be stronger at such institutions. On the other hand, if deposit insurance induces BHCs to take on more risks, then the impact of RMI should be felt more strongly at BHCs that rely heavily on deposits. To test these hypotheses, we define the dummy variable Low Deposits BHC to identify, in each year, BHCs that are in the lowest quartile in terms of their 
deposits to assets ratio. Consistent with the former interpretation, the coefficient on Low Deposits $B H C_{t-1} * R M I_{t-1}$ in Column (6) is negative and significant, which suggests that the impact of RMI in lowering aggregate risk is stronger at institutions that rely relatively less on deposits for their funding. The coefficient on the interaction term in the downside risk regression in Column (5), while negative, is not significant.

In Columns (7) and (8), we examine whether the impact of RMI in lowering risk is stronger in BHCs that are more active in trading derivatives off-balance sheet. Accordingly, we define the dummy variable High Deriv. Trading BHC to identify, in each year, BHCs that are in the top quartile in terms of the Deriv. Trading/Assets ratio. While the coefficient on High Deriv. Trading $B H C_{t-1}{ }^{*} R M I_{t-1}$ in Column (7) is negative, which is consistent with our hypothesis, it is not statistically significant at conventional levels of significance. We also find no evidence that the impact of RMI on aggregate risk varies with the BHC's derivative trading activity.

\subsection{Adjusting for Dynamic Endogeneity}

As we noted earlier, the identifying assumption behind the panel regression model (2) is that $R M I_{t-1}$ is exogenous, after controlling for the BHC's financial characteristics, ownership, governance, executive compensation, $\mathrm{BHC}$ and year fixed effects. This allows us to interpret the coefficient on $R M I_{t-1}$ as signifying the impact of $R M I_{t-1}$ on Risk $k_{t}$ However, our identifying assumption may not be valid if some unobserved time-varying omitted variable jointly affects both RMI and risk, or if the relationship between RMI and risk is dynamically endogenous; i.e., causation runs both ways, such that a BHC's past risk determines both current RMI and current risk (see Wintoki et al. (2010) for a discussion of dynamic endogeneity in a corporate finance setting).

In the context of our paper, dynamic endogeneity could arise in two different ways. The first possibility, which we refer to as the endogenous choice hypothesis is that BHCs exposed to greater risk endogenously choose stronger internal risk controls. If this hypothesis is true, it should bias against us finding a negative association between BHC Risk and RMI. Alternatively, it could be that the BHC's underlying risk culture determines both the choice of the risk and the strength of the risk management system; i.e., conservative BHCs take lower risks and put in place stronger risk management systems, while aggressive BHCs take higher risks and also have weaker internal risk controls. In this case, dynamic endogeneity will arise because past risk will itself be a proxy for the unobserved risk culture that affects

both RMI and future risk. If the risk-culture hypothesis is correct, it will tend to exaggerate the positive association between BHC risk and RMI.

The difficulty in dealing with dynamic endogeneity is that we do not have any exogenous 
instruments that we can use to consistently identify the impact of RMI on risk, because any observable variable that affects RMI also affects risk. In this section, we use a dynamic panel GMM estimator developed by Arellano and Bond (1991), that enables us to use the information from the BHC's history, in the form of lags of risk and other BHC characteristics, to provide instruments for identifying the relationship between RMI and risk. Specifically, we estimate the following dynamic model:

$$
\operatorname{Risk}_{j, t}=\alpha+\beta * \operatorname{RMI}_{j, t-1}+\kappa_{1} \operatorname{Risk}_{j, t-1}+\kappa_{2} \operatorname{Risk}_{j, t-2}+\gamma * X_{j, t-1}+\eta_{i}+\epsilon_{i t}
$$

Observe that model (3) employs two lags of the risk measure as regressor variables. This means that historical risk measures and $\mathrm{BHC}$ characteristics that are lagged three periods or more are available for use as exogenous instruments. The estimation of the model itself involves two steps: (i) first-differencing equation (3) to eliminate the unobserved $\eta_{i}$; and (ii) estimating the first-differenced equation via GMM using lagged values of risk and other BHC characteristics as possible instruments.

\section{[Insert Table VI here]}

The results of our estimation are presented in Table VI. The dependent variable in Columns (1) and (2) is Downside Risk. In Column (2), we employ the full set of control variables that we employed in Column (4) of Table IV, while in Column (1), we employ all the control variables with the exception of the CEO's Delta and Vega. As can be seen, the coefficient on $R M I_{t-1}$ continues to be negative and significant. In each column, we also present the results of the Sargan test for the validity of instruments employed in the

model. The Sargan test yields a statistic which is distributed $\chi^{2}$ under the null hypothesis of the validity of our instruments. The p-values of 0.142 and 0.607 in Columns (1) and (2) indicate that we cannot reject the null hypothesis that our instruments are valid.

In Columns (3) and (4), we repeat the estimation with Tail Risk and Aggregate Risk as the dependent variable, respectively. The empirical specification is the same as in Column (2). The negative coefficients on $R M I_{t-1}$ in both columns indicates that BHCs with strong internal risk controls have lower risk, even after controlling for the dynamic endogeneity between risk and RMI. The Sargan p-values of 0.432 and 0.474 in Columns (3) and (4) indicate that we cannot reject the null hypothesis that our instruments are valid.

Overall, the results in Table VI indicate that BHCs with a high $R M I$ in the previous year have lower enterprise-wide risk, even after controlling for any dynamic endogeneity between risk and internal risk controls.

Despite the economic appeal of the Arellano and Bond procedure, researchers have 
identified some econometric shortcomings (see Wintoki et al. (2010)): first-differencing may exacerbate the impact of measurement errors and reduce the power of tests, and variables in levels may be weak instruments for first-differenced equations. To test for the robustness of our results, we estimate a "System GMM" estimator developed by Arellano and Bover (1995) and Blundell and Bond (1998) that mitigates these shortcomings. The System GMM estimator improves on the Arellano and Bond procedure by also including the equations in levels in the estimation procedure, and by using lags of first-differenced variables as instruments for the equations in levels. Highlighting the robustness of our results, we find a negative association between $R M I_{t-1}$ and $R i s k_{t}$ even with the System GMM estimator. To conserve space, we do not report the results of this estimation in the paper, but these are available upon request.

\subsection{Impact of CRO Power and the Quality of Risk Oversight on Enterprise- wide Risk}

So far in our analysis, we have used the $R M I$ to capture the strength of internal risk controls within a BHC. Recall that we obtain the RMI by taking the first principal component of three variables that capture the CRO's relative power or importance within the BHC, and two variables that capture the quality of the risk oversight by the BHC's board of directors. As we mentioned in Section 2.2, the main advantage of using principal component analysis is that we do not have to make any subjective judgements regarding the relative importance of these different components. An obvious drawback of this approach is that we cannot say whether it is CRO power or the quality of risk oversight by the board that has a larger impact on enterprise-wide risk. This is the question that we turn to in this section.

Our approach in this section is to replicate some of our earlier analysis after replacing $R M I$ with the following two variables: CRO Centrality to proxy for the CRO's power within the BHC; and Quality of Oversight to proxy for the quality of risk oversight by the BHC's board of directors, and which is defined as the simple average of the two dummy variables, Risk Committee Experience and Active Board Risk Committee. ${ }^{19}$ The objective behind these regressions is to examine the relative importance of CRO power and quality of risk oversight in lowering enterprise-wide risk. The results must, however, be interpreted with a lot of caution because these two variables are not independent of each other. Consistent with our previous analysis, we investigate the impact of these variables on the outcomes during the financial crisis years, and also in the panel dataset that spans the period 2000-2008.

\footnotetext{
${ }^{19}$ We use a simple average to define Quality of Oversight because we do not have any idea about the relative individual importance of Risk Committee Experience and Active Board Risk Committee. We obtain qualitatively similar results when we estimate the regression with all the five $R M I$ components as separate regressor variables, instead of combining them into two categories. However, the interpretation of results is more meaningful with CRO Centrality and Quality of Oversight as the independent variables.
} 
The results of our estimation are presented in Table VII.

\section{[Insert Table VII here]}

In Panel A of Table VII, we replicate the key crisis-period regressions from Table III, after replacing $R M I_{2006}$ with CRO Centrality 2006 and Quality of Oversight ${ }_{2006}$. Otherwise, the empirical specification and control variables are the same as in Table III. Our objective is to examine whether it was CRO power or the quality of risk oversight by their boards, or both, that caused BHCs with high RMIs to fare relatively better during the crisis years (as we showed in Table III).

The negative and significant coefficients on Quality of Oversight 2006 in Columns (1) through (3) of Panel A indicate that BHCs with better quality of risk oversight had lower exposures to private-label mortgage-backed securities, risky trading assets, and off-balance sheet derivative trading activity during the crisis years. On the other hand, while the coefficients on CRO Centrality $_{2006}$ are negative, they are not statistically significant, indicating that CRO power had less of an impact on the BHC's exposures to these activities to start with. Interestingly, when we examine enterprise-wide risk measures in Columns (4) through (6), the picture reverses: the coefficients on CRO Centrality 2006 are now negative and significant, while the coefficients on Quality of Oversight 2006 are insignificant.

In Panel B of Table VII, we replicate the panel regressions in Table IV for the panel dataset that spans the period 2000-2008, after replacing $R M I_{t-1}$ with CRO Centrality t-1 $_{1}$ and Quality of Oversight $t_{t-1}$. The empirical specification and control variables are otherwise similar to that in Column (1) of Table IV. The dependent variables in Columns (1), (2) and (3) are Downside Risk, Tail Risk and Aggregate Risk, respectively.

As can be seen, in Columns (1) and (3), the coefficient on Quality of Oversight $_{t-1}$ is negative and significant, while the coefficient on CRO Centrality $t_{t-1}$ is negative but not statistically significant. This suggests that quality of risk oversight by the board is key to lowering aggregate risk and downside risk. However, when it comes to lowering tail risk, having a powerful CRO seems to be more important than the quality of risk oversight by the board. As stated at the outset, these findings must be interpreted with caution because CRO power and quality of risk oversight are not independently determined.

\subsection{Impact of RMI on Valuations}

So far, we have shown that BHCs with strong internal risk controls have lower enterprisewide risk, regardless of the risk measure employed. In this section, we examine if the stock market rewards or penalizes BHCs that have strong internal risk controls. The predictions 
for the impact of RMI on stock valuation are ambiguous. On the one hand, if strong internal risk controls cause the BHC to forgo profitable activities like asset management or derivatives trading, then it is possible that the stock market will penalize BHCs with high RMI. On the other hand, if strong risk controls can help a BHC avoid taking on excessive idiosyncratic risk, then the stock market should reward BHCs with high RMI. To test these hypotheses, we estimate the panel regression (2) with the BHC's Sharpe ratio as the dependent variable, which we compute by dividing the average daily risk premium on the BHC's stock (i.e., daily return on the BHC's stock minus the daily return on a 90-day treasury bill ) over the calendar year with the standard deviation of daily return. ${ }^{20}$ The Sharpe ratio denotes the risk-adjusted return on the BHC's stock. The empirical specification and control variables are exactly the same as in Table IV. The results of our estimation are presented in Table VIII.

\section{[Insert Table VIII here]}

The positive and statistically significant coefficient on $R M I_{t-1}$ in Column (1) indicates that BHCs with strong internal risk controls in place in the previous year have higher Sharpe ratios in the current year; i.e., the market rewards BHCs with strong internal risk controls. In terms of economic significance, the coefficient estimate indicates that a one standard deviation increase in RMI is associated with a $4.3 \%$ increase in the Sharpe Ratio. While the magnitude of this increase may seem very large, we must note that Sharpe ratios are highly variable in our sample, so that the $4.3 \%$ increase corresponds to a 0.8 standard deviation increase in the Sharpe ratio.

An oft-repeated argument in the popular press is that, in the years leading up to the financial crisis, the stock market cared mostly about returns, and less about risk-adjusted returns. This view implies that bank shareholders would be rewarded for taking excessive risks to achieve higher returns. In Column (2), we investigate if this argument is supported in our data. We do this by repeating the regression in Column (1) after including two additional regressors, Pre-Crisis and $R M I_{t-1} \times$ Pre-Crisis, where Pre-Crisis is a dummy variable that identifies the pre-crisis years, 2000-2006. As can be seen, the coefficient on $R M I_{t-1}$ continues to be positive. More importantly, the coefficient on the interaction term, $R M I_{t-1} \times$ Pre-Crisis, is positive and significant, which indicates that the positive association between $R M I_{t-1}$ and Sharpe ratios was stronger in the pre-crisis years. There are two possible interpretations for this result. First, it may be that, contrary to the popular view, the marginal investor did not overlook risk-adjusted returns in the years leading up to the financial crisis. Second, it may be that once the crisis hit, investors penalized BHCs across

\footnotetext{
${ }^{20}$ We obtain qualitatively similar results when we compute the Sharpe ratio using the weekly returns instead of the daily returns.
} 
the board regardless of their internal risk controls.

The positive association between $R M I_{t-1}$ and Sharpe Ratio $t$ is robust to controlling for the BHC's institutional ownership, corporate governance, and the CEO's compensation characteristics. The positive coefficient on CEO's Delta in Column (4) indicates that stock valuations are higher for BHCs whose CEOs have a large equity component in their compensation. We fail to detect any relationship between institutional ownership or G-Index and Sharpe ratio.

In Column (5), we estimate the Arellano-Bond specification to adjust for any dynamic endogeneity between risk-adjusted returns and the strength of internal risk controls. The empirical specification is similar to what we employed in Table VI. As can be seen, the coefficient on $R M I_{t-1}$ in Column (5) is positive and significant. Moreover, the Sargan p-value of 0.49 means that we cannot reject the hypothesis of validity of our instruments.

\section{Conclusion}

A prominent explanation for why many banks took excessive risks in the lead up to the financial crisis is that there was a failure of risk management functions at these banks. It is suggested that risk managers at banks either failed to identify or correctly measure risks, or failed to communicate risk exposures to their top management, or failed to monitor or manage risks adequately. As a result, they could not restrain traders and bank executives who, given their high-powered pay-for-performance schemes, had incentives to take excessive risks.

In this paper, we examine the organizational structure of the risk management function at bank holding companies (BHCs) in the United States, and ask whether BHCs with strong and independent risk controls in place had lower enterprise-wide risk. To this end, we construct an innovative risk management index that measures the strength and independence of the risk management function at each of the 74 largest publicly-listed BHCs.

We first show that BHCs with stronger risk controls in place before the onset of the financial crisis (i.e., higher levels of RMI in 2006) were more judicious in their risk taking, and fared relatively better during the crisis years. Specifically, such BHCs had lower exposure to private-label mortgage-backed securities and trading assets, were less active in trading off-balance sheet derivative securities, had a smaller fraction of non-performing loans, and had lower downside risk during the crisis years, 2007 and 2008.

We then show that the relationship between the strength of internal risk controls and enterprise-wide risk is not just confined to the crisis period, but also holds more generally 
during normal times. Examining a panel spanning the 9 year period from 2000-2008, we find that BHCs with stronger internal risk controls in the previous year have lower downside risk, lower tail risk, and lower aggregate risk in the current year. These results are obtained after controlling for various BHC characteristics like size, profitability, asset and liability composition including capital ratios, other risk characteristics, CEO's payperformance sensitivity, corporate governance, and BHC fixed effects. The results are also robust to controlling for any dynamic endogeneity between risk and internal risk controls.

Taken together, our results support the view that strong internal risk controls do matter, and play an important role in lowering enterprise-wide risk at banking institutions. 


\section{References}

Acharya, V., J. N. Carpenter, X. Gabaix, K. John, M. Richardson, M. G. Subrahmanyam, R. K. Sundaram, and E. Zemel (2009). Corporate governance in the modern financial sector. In: Acharya, V. and Richardson (Eds.) (2009), Restoring financial stability. Wiley Finance.

Acharya, V. V., L. H. Pedersen, T. Philippon, and M. Richardson (2009, November). Measuring systemic risk. NYU Working Paper.

Acharya, V. V., T. Philippon, M. Richardson, and N. Roubini (2009). The financial crisis of 2007-2009: Causes and remedies. In: Acharya, V. and Richardson (Eds.) (2009), Restoring financial stability. Wiley Finance.

Adams, R. and H. Mehran (2003). Is corporate governance different for bank holding companies? Federal Reserve Bank of New York Policy Review, 123-142.

Arellano, M. and S. Bond (1991). Panel data: Monte carlo evidence and an application to employment equations. Review of Economic Studies 58, 277-297.

Arellano, M. and O. Bover (1995). Another look at the instrumental variable estimation of error-components models. Journal of Econometrics 68, 29-51.

Bali, T. and A. Hovakimian (2009). Volatility spreads and expected stock returns. Forthcoming, Management Science.

Blundell, R. and S. Bond (1998). Initial conditions and moment restrictions in dynamic panel data models. Journal of Econometrics 87, 115-143.

Boyd, J. H. and M. Gertler (1994). Are banks dead? Or are the reports greatly exaggerated? Quarterly Review, Federal Reserve Bank of Minneapolis.

Calomiris, C. (2008). Statement before the committee on oversight and government reform. United States House of Representatives.

Calomiris, C. and D. Nissim (2007). Activity-based valuation of bank holding companies. NBER Working Paper 12918.

Core, J. E. and W. R. Guay (1999). The use of equity grants to manage optimal equity incentive levels. Journal of Accounting and Economics 28, 151-184.

Cremers, M. and D. Weinbaum (2008). Deviations from put-call parity and stock return predictability. Forthcoming, Journal of Financial and Quantitative Analysis. 
Demirgüç-Kunt, A. and E. Detragiache (2002). Does deposit insurance increase banking system stability? An empirical investigation. Journal of Monetary Economics 49, 13731406 .

Demsetz, R. S., M. R. Saidenberg, and P. E. Strahan (1997). Agency problems and risk taking at banks. Working paper, Banking Studies Department, Federal Reserve Bank of New York.

Demsetz, R. S. and P. E. Strahan (1997). Diversification, size and risk at bank holding companies. Journal of Money, Credit, and Banking 29(3), 300-313.

Diamond, D. (1984). Financial intermediation and delegated monitoring. Review of Economic Studies 51, 394-414.

Diamond, D. and R. Rajan (2001). Liquidity risk, liquidity creation, and financial fragility: A theory of banking. Journal of Political Economy 109(2), 287-327.

Diamond, D. and R. Rajan (2005). Liquidity shortages and banking crises. Journal of Finance 60(2), 615-647.

Erkens, D., M. Hung, and P. Matos (2009). Corporate governance in the recent financial crisis: Evidence from financial institutions worldwide. Working paper, University of Southern California, Los Angeles, CA.

Fahlenbrach, R. and R. M. Stulz (2009). Bank CEO incentives and the credit crisis. SSRN Working paper.

Froot, K., D. Scharfstein, and J. Stein (1993). Risk management : Coordinating corporate investment and financing policies. Journal of Finance 48, 1629-1658.

Gompers, P., J. Ishii, and A. Metrick (2003). Corporate governance and equity prices. Quarterly Journal of Economics 118(1), 107-155.

Hellmann, T. F., K. C. Murdock, and J. E. Stiglitz (2000). Liberalization, moral hazrd in banking, and prudential regulation: Are capital requirements enough? American Economic Review 90(1), 147-165.

Kashyap, A. K., R. G. Rajan, and J. C. Stein (2008). Rethinking capital regulation. NBER working paper.

Keeley, M. C. (1990). Deposit insurance, risk, and market power in banking. American Economic Review 80(5), 1183-1200.

Keys, B. J., T. Mukherjee, A. Seru, and V. Vig (2009). Financial regulation and securitization: Evidence from subprime loans. Journal of Monetary Economics 56, 700-720. 
Laeven, L. and R. Levine (2009). Bank governance, regulation and risk taking. Journal of Financial Economics 93, 259-275.

Landier, A., D. Sraer, and D. Thesmar (2008). Financial risk management: When does independence fail? Working Paper.

Liberti, J. M. (2005). Initiative, incentives and soft information. How does delegation impact the role of bank relationship managers? IFA Working Paper No. 404.

Macey, J. R. and M. O'Hara (2003, April). The corporate governance of banks. Federal Reserve Bank of New York Economic Policy Review, 91-107.

Mehran, H. and J. Rosenberg (2007). The effect of employee stock options on bank investment choice, borrowing, and capital. Federal Reserve Bank of New York Staff Report 305.

Purnanandam, A. (2007). Interest rate derivatives at commercial banks: An empirical investigation. Journal of Monetary Economics 54, 1769-1808.

Saunders, A., E. Strock, and N. G. Travlos (1990). Ownership structure, deregulation, and bank risk taking. Journal of Finance 45(2), 643-654.

Senior Supervisors Group (2008). Observation on risk management practices during the recent market turbulence.

Smith, C. and R. Stulz (1985). The determinants of firms' hedging policies. Journal of Financial and Quantitative Analysis 28, 391-405.

Stein, J. (2002). Information production and capital allocation: Decentralized versus hierarchial firms. Journal of Finance 57(5), 1891-1921.

Stulz, R. M. (2008). Risk management failures: What are they and when do they happen? Working paper, Ohio State University.

Wintoki, M. B., J. S. Linck, and J. M. Netter (2010). Endogeneity and the dynamics of internal corporate governance. Working Paper.

Xing, Y., X. Zhang, and R. Zhao (2008). What does individual option volatility smirk tell us about future equity returns? Forthcoming, Journal of Financial and Quantitative Analysis. 


\section{Appendix A: List of BHCs in our Sample}

\begin{tabular}{|c|c|c|}
\hline Name of BHC & 2007 Assets (\$ bn) & Time span in panel \\
\hline CITIGROUP INC. & 2188 & $2000-2008$ \\
\hline BANK OF AMERICA CORPORATION & 1721 & $2000-2008$ \\
\hline JPMORGAN CHASE \& CO. & 1562 & $2000-2008$ \\
\hline WACHOVIA CORPORATION & 783 & 2000-2007 \\
\hline WELLS FARGO \& COMPANY & 575 & $2000-2008$ \\
\hline METLIFE, INC. & 559 & $2002-2008$ \\
\hline BARCLAYS GROUP US INC. & 344 & $2005-2008$ \\
\hline U.S. BANCORP & 238 & $2000-2008$ \\
\hline SUNTRUST BANKS, INC. & 180 & $2000-2008$ \\
\hline CAPITAL ONE FINANCIAL CORPORATION & 151 & $2005-2008$ \\
\hline NATIONAL CITY CORPORATION & 150 & 2000-2007 \\
\hline STATE STREET CORPORATION & 143 & 2000-2008 \\
\hline REGIONS FINANCIAL CORPORATION & 141 & $2005-2008$ \\
\hline PNC FINANCIAL SERVICES GROUP, INC., THE & 139 & $2000-2008$ \\
\hline BB\&T CORPORATION & 133 & $2000-2008$ \\
\hline FIFTH THIRD BANCORP & 111 & 2000-2008 \\
\hline KEYCORP & 100 & 2000-2008 \\
\hline BANCWEST CORPORATION & 74 & 2001-2008 \\
\hline NORTHERN TRUST CORPORATION & 68 & 2000-2008 \\
\hline M\&T BANK CORPORATION & 65 & $2000-2008$ \\
\hline COMERICA INCORPORATED & 63 & $2000-2008$ \\
\hline UnionBancal Corp & 56 & $2000-2008$ \\
\hline HUNTINGTON BANCSHARES INCORPORATED & 55 & $2000-2008$ \\
\hline ZIONS BANCORPORATION & 53 & 2000-2008 \\
\hline COMMERCE BANCORP, INC. & 49 & 2000-2007 \\
\hline POPULAR, INC. & 44 & $2000-2008$ \\
\hline FIRST HORIZON NATIONAL CORPORATION & 37 & $2000-2008$ \\
\hline SYNOVUS FINANCIAL CORP. & 33 & $2000-2008$ \\
\hline NEW YORK COMMUNITY BANCORP, INC. & 31 & $2000-2008$ \\
\hline COLONIAL BANCGROUP, INC., THE & 26 & $2000-2008$ \\
\hline ASSOCIATED BANC-CORP & 22 & 2000-2008 \\
\hline BOK Financial Corp & 21 & 2000-2008 \\
\hline W HOLDING COMPANY, INC. & 18 & $2000-2008$ \\
\hline WEBSTER FINANCIAL CORPORATION & 17 & $2005-2008$ \\
\hline FIRST BANCORP & 17 & 2000-2008 \\
\hline FIRST CITIZENS BANCSHARES, INC. & 16 & 2000-2008 \\
\hline COMMERCE BANCSHARES, INC. & 16 & 2000-2008 \\
\hline TCF FINANCIAL CORPORATION & 16 & 2000-2008 \\
\hline FULTON FINANCIAL CORPORATION & 16 & $2000-2008$ \\
\hline
\end{tabular}




\begin{tabular}{|c|c|c|}
\hline Name of BHC & 2007 Assets (\$ bn) & Time span in panel \\
\hline CITY NATIONAL CORPORATION & 16 & $2000-2008$ \\
\hline SOUTH FINANCIAL GROUP, THE & 14 & $2000-2008$ \\
\hline CULLEN/FROST BANKERS, INC. & 14 & $2000-2008$ \\
\hline CITIZENS REPUBLIC BANCORP, INC. & 14 & $2000-2008$ \\
\hline BANCORPSOUTH, INC. & 13 & $2000-2008$ \\
\hline SUSQUEHANNA BANCSHARES, INC. & 13 & $2000-2008$ \\
\hline VALLEY NATIONAL BANCORP & 13 & $2000-2008$ \\
\hline STERLING FINANCIAL CORPORATION & 12 & $2006-2008$ \\
\hline EAST WEST BANCORP, INC. & 12 & $2000-2008$ \\
\hline UCBH HOLDINGS, INC. & 12 & $2000-2008$ \\
\hline WILMINGTON TRUST CORPORATION & 12 & $2000-2008$ \\
\hline INTERNATIONAL BANCSHARES CORPORATION & 11 & $2000-2008$ \\
\hline WHITNEY HOLDING CORPORATION & 11 & $2000-2008$ \\
\hline BANK OF HAWAII CORPORATION & 10 & $2000-2008$ \\
\hline FIRSTMERIT CORPORATION & 10 & $2000-2008$ \\
\hline CATHAY GENERAL BANCORP & 10 & $2000-2008$ \\
\hline FRANKLIN RESOURCES, INC. & 10 & $2002-2008$ \\
\hline WINTRUST FINANCIAL CORPORATION & 9 & $2000-2008$ \\
\hline UMB FINANCIAL CORPORATION & 9 & $2000-2008$ \\
\hline SANTANDER BANCORP & 9 & $2001-2008$ \\
\hline TRUSTMARK CORPORATION & 9 & $2000-2008$ \\
\hline CORUS BANKSHARES, INC. & 9 & $2000-2007$ \\
\hline FIRSTBANK HOLDING COMPANY & 9 & $2000-2008$ \\
\hline UMPQUA HOLDINGS CORPORATION & 8 & $2000-2008$ \\
\hline NEWALLIANCE BANCSHARES, INC. & 8 & $2005-2008$ \\
\hline UNITED COMMUNITY BANKS, INC. & 8 & $2000-2008$ \\
\hline FIRST MIDWEST BANCORP, INC. & 8 & $2000-2008$ \\
\hline ALABAMA NATIONAL BANCORPORATION & 8 & $2000-2007$ \\
\hline UNITED BANKSHARES, INC. & 8 & $2000-2008$ \\
\hline OLD NATIONAL BANCORP & 8 & $2000-2008$ \\
\hline MB FINANCIAL, INC & 8 & $2000-2008$ \\
\hline CHITTENDEN CORPORATION & 7 & $2000-2007$ \\
\hline PACIFIC CAPITAL BANCORP & 7 & $2000-2008$ \\
\hline BOSTON PRIVATE FINANCIAL HOLDINGS, INC. & 7 & $2000-2008$ \\
\hline PARK NATIONAL CORPORATION & 7 & 2000-2007 \\
\hline
\end{tabular}




\section{Appendix B: Definitions of key variables}

\section{BHC Risk Measures:}

- Aggregate Risk: Standard deviation of the BHC's weekly excess returns (i.e., weekly return on BHC stock less weekly return on the S\&P500) over the year.

- Downside Risk: Mean implied volatility estimated from put options written on the BHC's stock.

- Tail Risk: The marginal expected shortfall (MES) measure proposed by Acharya et al. (2009). In a given year, the MES is defined as the negative of the average return on the BHC's stock during the $5 \%$ worst days for the S\&P500.

\section{BHC Risk Management Measures:}

- CRO Present: A dummy variable that identifies if the BHC reports that it has a designated Chief Risk Officer (or a Chief Credit Officer, or a Chief Lending Officer).

- CRO Executive: A dummy variable that identifies if the Chief Risk Officer (or Chief Lending Officer, or Chief Credit Officer) is an executive officer.

- CRO-Top5: A dummy variable that identifies if the Chief Risk Officer (or Chief Lending Officer or Chief Credit Officer) is among the five highest paid executives.

- CRO Centrality: Ratio of the CRO's total compensation to the CEO's total compensation. When the $\mathrm{BHC}$ has a $\mathrm{CRO}$ who does not figure among the five highest paid executives, we calculate $C R O$ Centrality based on the compensation of the fifth highest-paid executive, and subtract a percentage point from the resultant ratio. In case of BHCs that do not report having a $\mathrm{CRO}$, we define CRO Centrality based on the total compensation of the Chief Financial Officer if that is available; if CFO compensation is not available, then we compute CRO Centrality based on the compensation of the fifth highest-paid executive, and subtract a percentage point from the resulting ratio.

- Risk Committee Experience: A dummy variable that takes the value of 1 if at least one of the noninside directors serving on the board's risk committee has prior banking experience, and 0 otherwise.

- Freq. Meetings of Risk Committee: The number of times the BHC's board risk committee met during the year.

- Active Risk Committee: A dummy variable that takes the value of 1 if the frequency with which the BHC's board risk committee met during the year is higher than the average frequency across all BHCs during the year, and 0 otherwise. 
- Quality of Oversight: Equals the simple average of the dummy variables, Risk Committee Experience and Active Risk Committee.

- Frac. Experienced Directors: The fraction of non-inside directors on the BHC's board of directors that have prior banking or financial industry experience.

- Experienced Board: A dummy variable that takes the value of 1 if Frac. Experienced Directors for the $\mathrm{BHC}$ is higher than the average value across all BHCs during the year, and 0 otherwise.

- Reports to Board: A dummy variable that identifies whether the key management-level risk committee (usually called the "Asset and Liability Committee") reports directly to the BHC's board of directors, instead of to the CEO.

- $R M I$ : Computed as the first principal component of the following five risk management variables over the time period 1999-2007: CRO Executive, CRO-Top5, CRO Centrality, Risk Committee Experience, and Active Risk Committee.

- Alt. RMI: Computed as the first principal component of the following seven risk management variables over the time period 1999-2007: CRO Present, CRO Executive, CRO-Top5, CRO Centrality, Risk Committee Experience, Reports to Board and Active Risk Committee.

- Alt. RMI 2: Computed as the first principal component of the following six risk management variables over the time period 1999-2007: CRO Executive, CRO-Top5, CRO Centrality, Risk Committee Experience, Active Risk Committee, and Experienced Board.

\section{BHC financial characteristics:}

The expressions within the parentheses denote the corresponding variable names in the FR Y-9C reports.

- Size: Natural logarithm of the book value of total assets (BHCK2170).

- ROA: Ratio of the income before extraordinary items (BHCK4300) to assets.

- Deposits/Assets: Ratio of total deposits (BHDM6631+BHDM6636+BHFN6631+BHFN6636) to assets.

- Core Deposits/Assets: Ratio of "core" deposits to assets, where core deposits include deposits held in domestic offices of the subsidiaries of the BHC, excluding all time deposits of over $\$ 100,000$ and any brokered deposits (BHCB2210+ BHCB3187+ BHCB2389+ BHCB6648+ BHOD3189+ BHOD3187+ BHOD2389+ BHOD6648- BHDMA243- BHDMA164).

- Non-Core Deposits/Assets: Ratio of (total deposits-core deposits) to assets. 
- Tier-1 Cap/Assets: Ratio of Tier1 capital (BHCK8274) to assets.

- Loans/Assets: Ratio of total loans (BHCK2122) to assets.

- Real Estate Loans/Assets: Ratio of loans secured by real estate (BHCK1410) to assets.

- CEII Loans/Assets: Ratio of commercial and industrial loans (BHDM1766) to assets.

- Consumer Loans/Assets: Ratio of consumer loans (BHDM1975) to assets.

- Agri. Loans/Assets: Ratio of agricultural loans (BHCK1590) to assets.

- Other Loans/Assets: Ratio of all other loans to assets.

- Loan Concentration: Measures the concentration of the BHC's loan portfolio among the five loan segments defined above. It is computed as the sum of squares of each segment's share in the total loan portfolio.

- Bad Loans/Assets: Ratio of the sum of loans past due 90 days or more (BHCK5525) and non-accrual loans (BHCK5526) to assets.

- Non-Int. Income/Income: Ratio of non-interest income (BHCK4079) to the sum of interest income (BHCK4107) and non-interest income (BHCK4079).

- UW Assets/Assets: The ratio of the assets of subsidiaries engaged in underwriting or dealing securities (BHCKC252) to the total assets of the BHC.

- Ins. Assets/Assets: The ratio of the assets of subsidiaries engaged in insurance and reinsurance (BHCKC253) to the total assets of the BHC.

- Private $M B S$ : The total value of private-label mortgage backed securities held in both trading and investment portfolios; i.e., this excludes mortgage-backed securities that are either issued or guaranteed by government sponsored enterprises. This measure is computed as summing the following variables: BHCK1709, BHCK1733, BHCK1713, BHCK1736 and BHCK3536.

- Risky Trading Assets: Total trading assets (BHCK3545) less investments in U.S. treasury securities (BHCK3531), U.S. government agency obligations (BHCK3532), securities issued by states and political subdivisions in the U.S. (BHCK3533), and mortgage backed securities issued or guaranteed by government sponsored enterprises (BHCK3534 and BHCK3535).

- Deriv. Trading: Total gross notional amount of derivative contracts held for trading, obtained by adding amounts on interest rate contracts (BHCKA126), foreign exchange contracts (BHCKA127), equity derivative contracts (BHCK8723), and commodity and other contracts (BHCK8724).

- Deriv. Hedging: Value of derivatives used for hedging purposes. Obtained by adding the following variables: BHCK8725, BHCK8726, BHCK8727 and BHCK8728. 


\section{Other BHC Variables:}

- Sharpe Ratio: The average daily risk premium on the BHC's stock (i.e., daily return on the BHC's stock minus the daily return on a 90-day treasury bill) over the calendar year divided by the standard deviation of the daily return.

- Inst. Ownership: Percentage of shares owned by 13-F institutional investors.

- G-Index: Gompers, Ishii and Metrick (2003) governance index.

- CEO's Delta: Sensitivity of CEO compensation to share price, expressed in $\$$ '000.

- CEO's Vega: Sensitivity of CEO compensation to stock return volatility, expressed in $\$$ '000. 
Figure 1. Downside Risk during Crisis Years vs. Pre-Crisis RMI

This figure plots the average Downside Risk of each BHC over the crisis years (2007 and 2008) versus its corresponding pre-crisis RMI, which is defined as the average RMI of the BHC over the period 2003-2006. The solid straight line in the figure is a plot of predicted values obtained from a regression of Downside Risk versus a constant and the pre-crisis RMI.

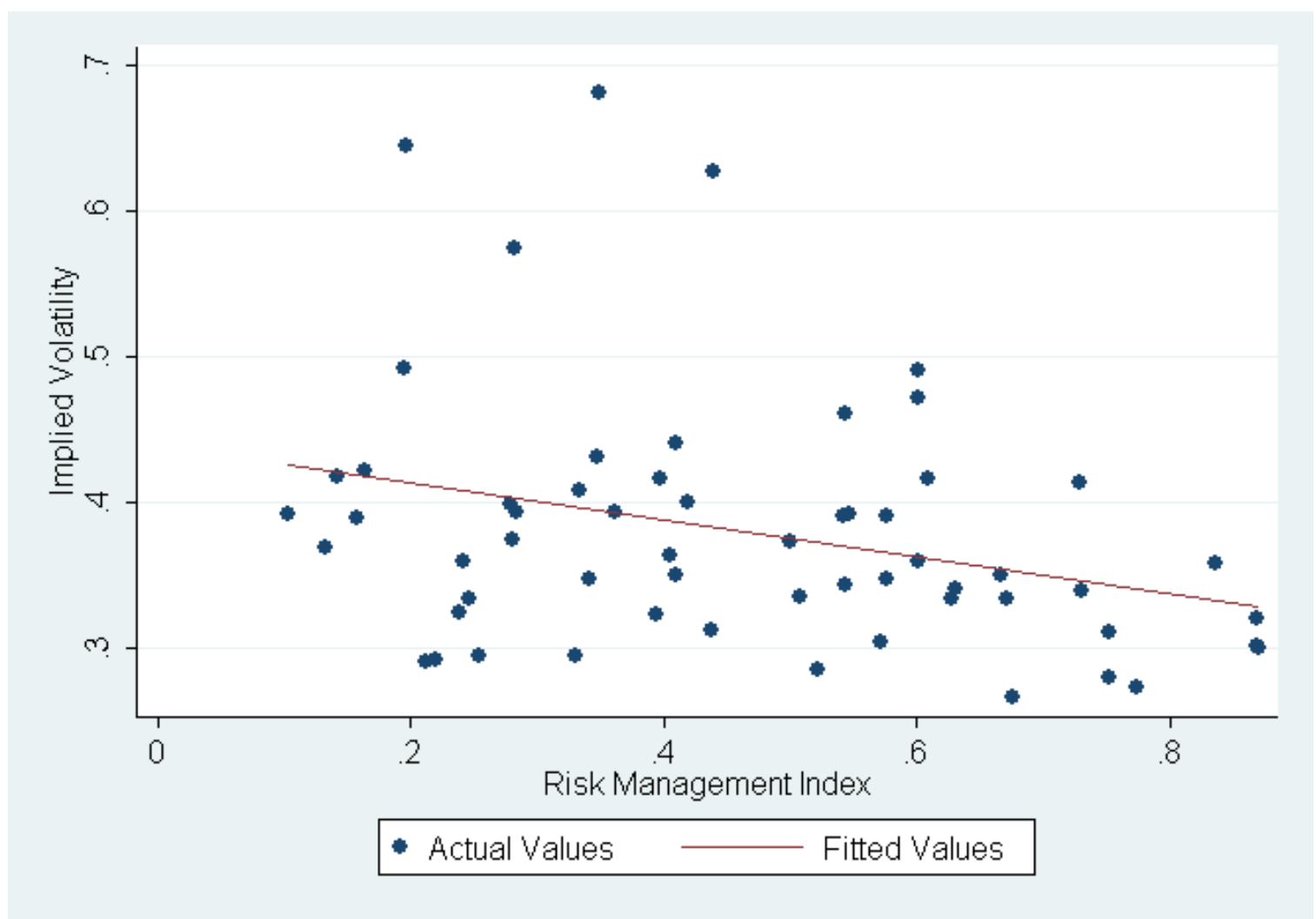


Figure 2. Downside Risk during Crisis Years vs. Pre-Crisis CRO Centrality

This figure plots the average Downside Risk of each BHC over the crisis years (2007 and 2008) versus its corresponding pre-crisis CRO Centrality, which is defined as the average CRO Centrality of the BHC over the period 2003-2006. The solid straight line in the figure is a plot of predicted values obtained from a regression of Downside Risk versus a constant and the pre-crisis CRO Centrality.

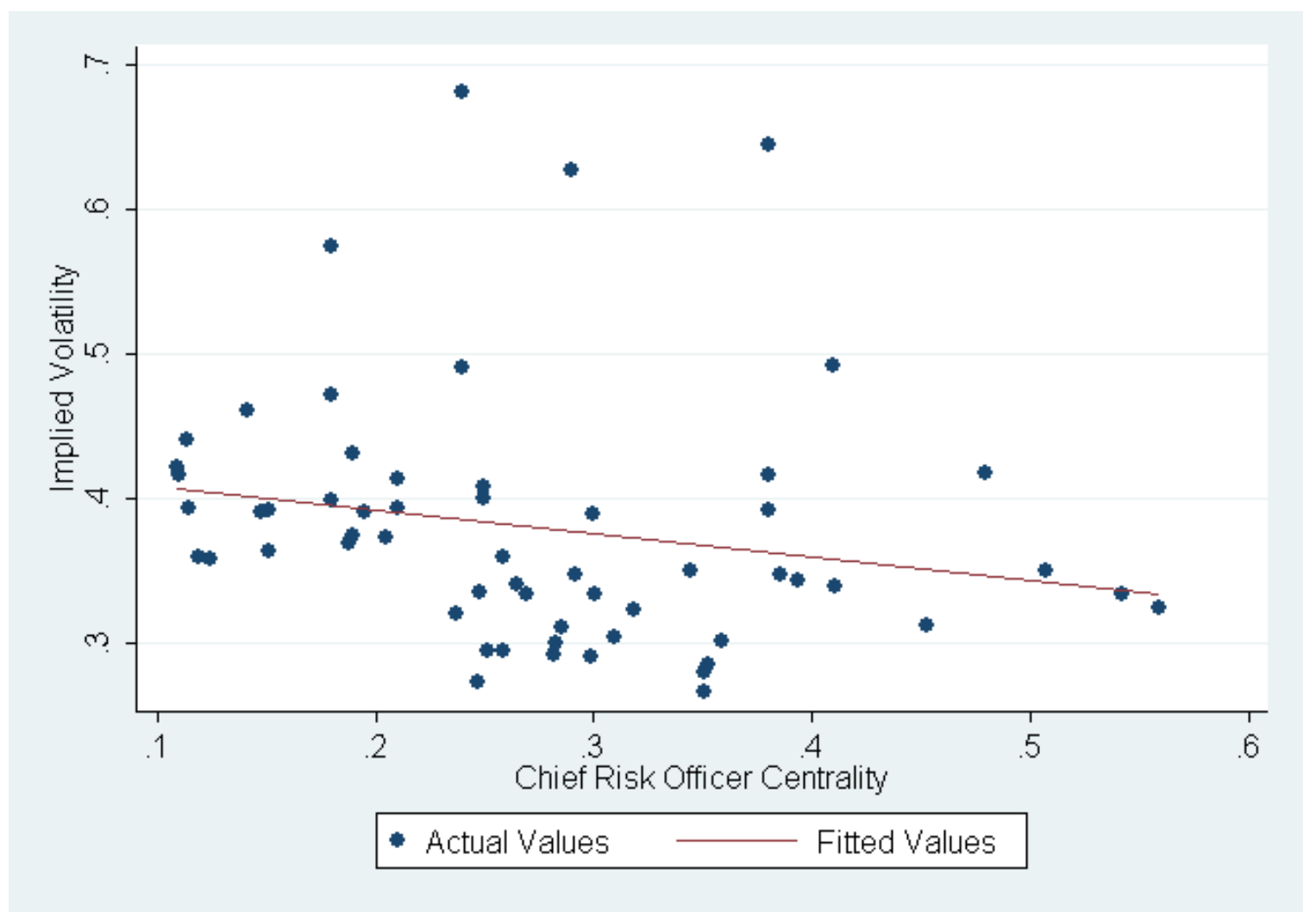




\section{Table I: Summary Statistics}

This table presents the descriptive statistics for the key variables used in our analysis. Downside Risk is defined as the mean implied volatility estimated from put options written on the BHC's stock. Tail Risk is defined as the negative of the average return on the BHC's stock over the $5 \%$ worst days for the S\&P500 during the year. Aggregate Risk is the standard deviation of the BHC's weekly excess return (over S\&P500), computed over the year. $R M I$ measures the strength and independence of the risk management function at a BHC. All other variables are defined in Appendix B.

\begin{tabular}{|c|c|c|c|c|c|c|}
\hline & Mean & Median & Std. Dev. & p25 & p75 & $\mathbf{N}$ \\
\hline Downside Risk & 0.397 & 0.350 & 0.172 & 0.281 & 0.451 & 400 \\
\hline Tail Risk & 0.025 & 0.016 & 0.024 & 0.011 & 0.028 & 697 \\
\hline Aggregate Risk & 0.038 & 0.031 & 0.024 & 0.022 & 0.044 & 698 \\
\hline Annual Return & 0.046 & 0.046 & 0.293 & -0.121 & 0.215 & 698 \\
\hline RMI & 0.451 & 0.410 & 0.207 & 0.309 & 0.609 & 673 \\
\hline Alt. RMI & 0.427 & 0.392 & 0.201 & 0.297 & 0.583 & 673 \\
\hline CRO Present & 0.618 & 1 & 0.482 & 0 & 1 & 673 \\
\hline CRO Executive & 0.519 & 0 & 0.479 & 0 & 1 & 673 \\
\hline CRO Top5 & 0.195 & 0 & 0.393 & 0 & 0 & 673 \\
\hline CRO Centrality & .324 & .262 & .182 & .194 & .352 & 673 \\
\hline Risk Committee Experience & .232 & 0 & .422 & 0 & 0 & 673 \\
\hline Frac. Experienced Directors & 0.225 & 0.217 & 0.092 & 0.200 & 0.360 & 673 \\
\hline Experienced Board & .482 & 0 & .402 & 0 & 1 & 673 \\
\hline Freq. of meetings: Risk Committee & 5.052 & 3 & 5.321 & 0 & 8 & 673 \\
\hline Active Risk Committee & 0.462 & 0 & 0.481 & 0 & 1 & 673 \\
\hline Report to Board & 0.518 & 1 & 0.500 & 0 & 1 & 673 \\
\hline Assets (in $\$$ billion) & 86.083 & 12.437 & 244.625 & 7.298 & 45.587 & 904 \\
\hline Size & 16.806 & 16.336 & 1.473 & 15.803 & 17.635 & 904 \\
\hline $\mathrm{ROA}$ & 0.010 & 0.011 & 0.013 & 0.008 & 0.014 & 904 \\
\hline Deposits/Assets & 0.661 & 0.686 & 0.170 & 0.614 & 0.765 & 900 \\
\hline Tier-1 Cap/ Assets & 0.077 & 0.074 & 0.040 & 0.065 & 0.084 & 899 \\
\hline Loans/ Assets & 0.611 & 0.664 & 0.165 & 0.561 & 0.716 & 904 \\
\hline Bad Loans/Assets & 0.007 & 0.005 & 0.010 & 0.003 & 0.008 & 904 \\
\hline Non-int Income/Income & 0.235 & 0.211 & 0.131 & 0.148 & 0.298 & 904 \\
\hline UW Assets/Assets & 0.013 & 0 & 0.071 & 0 & 0 & 904 \\
\hline Ins. Assets/Assets & 0.008 & 0 & 0.082 & 0 & 0 & 904 \\
\hline Deriv. Hedging/Assets & 0.092 & 0.030 & 0.179 & 0.002 & 0.101 & 904 \\
\hline Deriv. Trading/Assets & 0.974 & 0.000 & 4.646 & 0 & 0.117 & 904 \\
\hline Inst. Ownership & 0.468 & 0.486 & 0.217 & 0.305 & 0.632 & 625 \\
\hline G-Index & 9.623 & 9 & 2.814 & 8 & 12 & 509 \\
\hline CEO's Delta (in $\$$ '000) & 0.011 & 0.004 & 0.021 & 0.002 & 0.012 & 405 \\
\hline CEO's Vega (in \$ '000) & 0.144 & 0.054 & 0.270 & 0.015 & 0.140 & 384 \\
\hline
\end{tabular}




\section{Table II: Correlations among Key Variables}

This table presents the correlations between the key variables used in our analysis. Panel A presents the correlations between BHC risk measures, Risk Management Index (RMI), and BHC characteristics. Panel $\mathrm{B}$ presents the correlations between BHC risk measures and components of the RMI. Variable definitions are in Appendix B.

Panel A: Correlations between BHC Risk, RMI, and BHC Characteristics

\begin{tabular}{|c|c|c|c|c|c|}
\hline & Downside Risk & Tail Risk & Aggregate Risk & $\mathrm{RMI}_{t-1}$ & Size $_{t-1}$ \\
\hline Downside Risk & 1 & & & & \\
\hline Tail Risk & 0.728 & 1 & & & \\
\hline Aggregate Risk & 0.802 & 0.877 & 1 & & \\
\hline $\mathrm{RMI}_{t-1}$ & -0.262 & -0.017 & -0.093 & 1 & \\
\hline Size $_{t-1}$ & -0.135 & 0.13 & 0.031 & 0.44 & 1 \\
\hline $\mathrm{ROA}_{t-1}$ & -0.065 & -0.041 & -0.091 & -0.089 & -0.137 \\
\hline$(\text { Tier-1 Cap/Assets })_{t-1}$ & -0.004 & -0.015 & -0.051 & -0.134 & -0.249 \\
\hline$(\text { Deposits } / \text { Assets })_{t-1}$ & -0.004 & -0.104 & -0.068 & -0.039 & -0.49 \\
\hline$(\text { Bad Loans/Assets })_{t-1}$ & 0.182 & 0.212 & 0.251 & 0.279 & 0.186 \\
\hline (Non-int income/Income $)_{t-1}$ & -0.186 & -0.085 & -0.19 & 0.099 & 0.385 \\
\hline$(\mathrm{UW} \text { Assets/Assets) })_{t-1}$ & 0.038 & 0.12 & 0.073 & 0.061 & 0.365 \\
\hline$(\text { Ins. Assets/Assets })_{t-1}$ & -0.044 & -0.007 & -0.014 & -0.135 & 0.223 \\
\hline$(\text { Deriv Trading/Assets) })_{t-1}$ & -0.035 & 0.069 & 0.019 & 0.155 & 0.599 \\
\hline$(\text { Deriv Hedging/Assets })_{t-1}$ & -0.171 & -0.029 & -0.111 & 0.112 & 0.435 \\
\hline Inst. Ownership ${ }_{t-1}$ & 0.175 & 0.208 & 0.173 & -0.172 & -0.015 \\
\hline G-Index $t-1$ & 0.125 & 0.059 & 0.065 & -0.034 & -0.35 \\
\hline CEO's Delta ${ }_{t-1}$ & 0.142 & 0.02 & 0.044 & -0.219 & -0.281 \\
\hline CEO's Vega $t-1$ & 0.017 & 0.258 & 0.103 & 0.204 & 0.508 \\
\hline
\end{tabular}

Panel B: Correlations between BHC Risk and Components of RMI

\begin{tabular}{l|cccc}
\hline & Downside Risk & Tail Risk & Aggregate Risk & RMI $_{t-1}$ \\
\hline CRO Executive $_{t-1}$ & -0.210 & -0.079 & -0.085 & 0.521 \\
CRO Top5 $_{t-1}$ & -0.019 & -0.010 & 0.019 & 0.372 \\
CRO Centrality $_{t-1}$ & -0.189 & -0.112 & -0.151 & 0.488 \\
Risk Committee Experience $_{t-1}$ & -0.096 & 0.008 & 0.009 & 0.412 \\
Active Risk Committee $_{t-1}$ & -0.153 & -0.009 & -0.118 & 0.308 \\
CRO Present $_{t-1}$ & -0.272 & -0.078 & -0.0815 & 0.511 \\
Experienced Board $_{t-1}$ & -0.198 & -0.011 & -0.092 & 0.380 \\
\hline
\end{tabular}




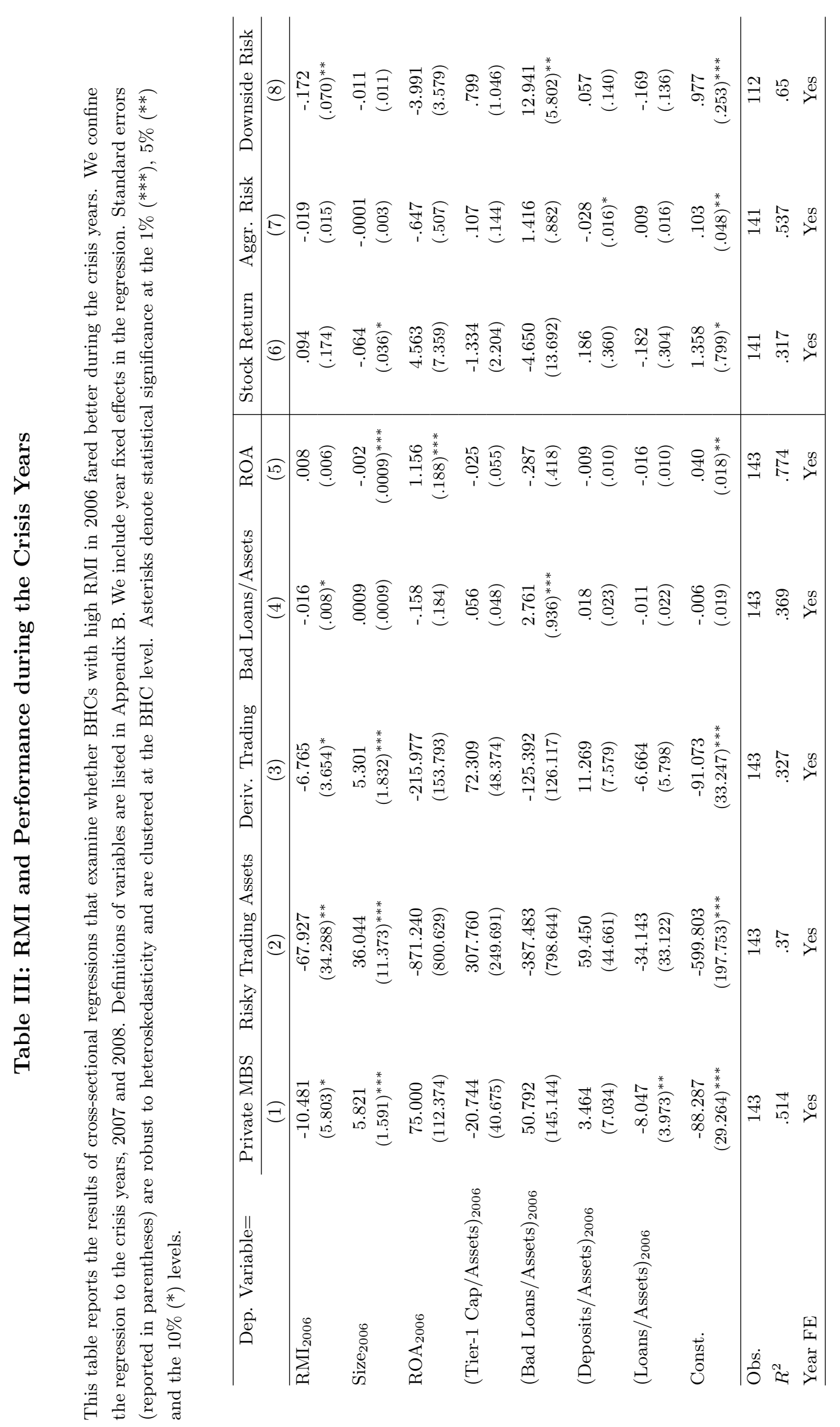




\section{Table IV: Impact of RMI on Enterprise-Wide Risk}

This table reports the results of panel regressions that examine the impact of a BHC's risk management index (RMI) on its enterprise-wide risk. We estimate the regressions on a panel that has one observation for each BHC-year combination, and spans the time period 2000-2008. We include BHC fixed effects and year fixed effects in all specifications. Standard errors (reported in parentheses) are robust to heteroskedasticity, and are clustered at the BHC level. Asterisks denote statistical significance at the $1 \%(* * *), 5 \%(* *)$ and $10 \%(*)$ levels.

The dependent variable in Panel A is Downside Risk, which is defined as the mean implied volatility estimated from put options written on the BHC's stock. The dependent variable in Panel B is Tail Risk, which is defined as the negative of the average return on the BHC's stock over the 5\% worst days for the S\&P500 during the year. The dependent variable in Panel C is Aggregate Risk, which is defined as the standard deviation of the weekly excess return on the BHC's stock (over the S\&P500) during the year. All other variables are defined in Appendix B. 
Panel A: Impact of RMI on Downside Risk

\begin{tabular}{|c|c|c|c|c|c|}
\hline & \multicolumn{5}{|c|}{ Mean Implied Volatility of Put Options } \\
\hline & (1) & $(2)$ & $(3)$ & $(4)$ & $(5)$ \\
\hline $\mathrm{RMI}_{t-1}$ & $\begin{array}{c}-.325 \\
(.187)^{*}\end{array}$ & $\begin{array}{c}-.407 \\
(.174)^{* *}\end{array}$ & $\begin{array}{c}-.442 \\
(.193)^{* *}\end{array}$ & $\begin{array}{c}-.526 \\
(.261)^{* *}\end{array}$ & \\
\hline Alt. $\mathrm{RMI}_{t-1}$ & & & & & $\begin{array}{c}-.714 \\
(.368)^{*}\end{array}$ \\
\hline $\operatorname{Size}_{t-1}$ & $\begin{array}{c}.004 \\
(.033)\end{array}$ & $\begin{array}{l}-.015 \\
(.042)\end{array}$ & $\begin{array}{l}-.013 \\
(.042)\end{array}$ & $\begin{array}{l}-.023 \\
(.049)\end{array}$ & $\begin{array}{l}-.021 \\
(.051)\end{array}$ \\
\hline $\mathrm{ROA}_{t-1}$ & $\begin{array}{l}-1.102 \\
(1.013)\end{array}$ & $\begin{array}{c}-.394 \\
(1.197)\end{array}$ & $\begin{array}{c}-.558 \\
(1.186)\end{array}$ & $\begin{array}{c}-.979 \\
(2.838)\end{array}$ & $\begin{array}{c}-.706 \\
(2.981)\end{array}$ \\
\hline Annual Stock Return ${ }_{t-1}$ & $\begin{array}{c}-.069 \\
(.018)^{* * *}\end{array}$ & $\begin{array}{c}-.077 \\
(.018)^{* * *}\end{array}$ & $\begin{array}{c}-.072 \\
(.019)^{* * *}\end{array}$ & $\begin{array}{c}-.068 \\
(.021)^{* * *}\end{array}$ & $\begin{array}{c}-.070 \\
(.021)^{* * *}\end{array}$ \\
\hline$(\text { Deposits/Assets })_{t-1}$ & $\begin{array}{c}.273 \\
(.159)^{*}\end{array}$ & $\begin{array}{c}.240 \\
(.157)\end{array}$ & $\begin{array}{c}.248 \\
(.157)\end{array}$ & $\begin{array}{c}.148 \\
(.167)\end{array}$ & $\begin{array}{c}.137 \\
(.168)\end{array}$ \\
\hline$(\text { Tier-1 Cap/Assets })_{t-1}$ & $\begin{array}{l}-.338 \\
(.490)\end{array}$ & $\begin{array}{l}-.555 \\
(.621)\end{array}$ & $\begin{array}{l}-.489 \\
(.585)\end{array}$ & $\begin{array}{l}-1.062 \\
(.578)^{*}\end{array}$ & $\begin{array}{c}-1.167 \\
(.580)^{* *}\end{array}$ \\
\hline$(\text { Loans/Assets })_{t-1}$ & $\begin{array}{l}-.094 \\
(.153)\end{array}$ & $\begin{array}{c}.015 \\
(.113)\end{array}$ & $\begin{array}{c}.024 \\
(.115)\end{array}$ & $\begin{array}{c}.026 \\
(.124)\end{array}$ & $\begin{array}{c}.021 \\
(.120)\end{array}$ \\
\hline$(\text { Bad Loans/Assets })_{t-1}$ & $\begin{array}{c}9.153 \\
(3.365)^{* * *}\end{array}$ & $\begin{array}{c}5.675 \\
(3.576)\end{array}$ & $\begin{array}{c}5.752 \\
(3.484)^{*}\end{array}$ & $\begin{array}{c}5.594 \\
(2.887)^{*}\end{array}$ & $\begin{array}{c}5.399 \\
(2.823)^{*}\end{array}$ \\
\hline (Non-int. income/Income) $)_{t-1}$ & $\begin{array}{c}.066 \\
(.152)\end{array}$ & $\begin{array}{c}.041 \\
(.135)\end{array}$ & $\begin{array}{c}.047 \\
(.133)\end{array}$ & $\begin{array}{c}.068 \\
(.139)\end{array}$ & $\begin{array}{c}.056 \\
(.143)\end{array}$ \\
\hline$(\mathrm{UW} \mathrm{Assets} / \text { Assets })_{t-1}$ & & $\begin{array}{l}-.236 \\
(.114)^{* *}\end{array}$ & $\begin{array}{l}-.160 \\
(.111)\end{array}$ & $\begin{array}{l}-.229 \\
(.113)^{* *}\end{array}$ & $\begin{array}{c}-.221 \\
(.118)^{*}\end{array}$ \\
\hline$(\text { Ins. Assets/Assets })_{t-1}$ & & $\begin{array}{c}-.049 \\
(.020)^{* *}\end{array}$ & $\begin{array}{c}-.044 \\
(.022)^{* *}\end{array}$ & $\begin{array}{c}.349 \\
(4.298)\end{array}$ & $\begin{array}{c}1.023 \\
(4.701)\end{array}$ \\
\hline Inst. Ownership $t-1$ & & $\begin{array}{c}.314 \\
(.111)^{* * *}\end{array}$ & $\begin{array}{c}.305 \\
(.110)^{* * *}\end{array}$ & $\begin{array}{c}.286 \\
(.141)^{* *}\end{array}$ & $\begin{array}{c}.283 \\
(.139)^{* *}\end{array}$ \\
\hline G-Index $t-1$ & & $\begin{array}{l}-.004 \\
(.013)\end{array}$ & $\begin{array}{l}-.004 \\
(.013)\end{array}$ & $\begin{array}{c}-.00009 \\
(.014)\end{array}$ & $\begin{array}{c}-.0009 \\
(.016)\end{array}$ \\
\hline$(\text { Deriv Trading/Assets })_{t-1}$ & & & $\begin{array}{l}-.001 \\
(.002)\end{array}$ & $\begin{array}{c}-.0003 \\
(.002)\end{array}$ & $\begin{array}{l}.00008 \\
(.002)\end{array}$ \\
\hline (Deriv Hedging/Assets) ${ }_{t-1}$ & & & $\begin{array}{l}-.075 \\
(.043)^{*}\end{array}$ & $\begin{array}{l}-.060 \\
(.046)\end{array}$ & $\begin{array}{l}-.061 \\
(.048)\end{array}$ \\
\hline CEO's Delta $t-1$ & & & & $\begin{array}{l}-.839 \\
(.626)\end{array}$ & $\begin{array}{l}-.767 \\
(.607)\end{array}$ \\
\hline CEO's Vega ${ }_{t-1}$ & & & & $\begin{array}{l}-.014 \\
(.029)\end{array}$ & $\begin{array}{l}-.017 \\
(.028)\end{array}$ \\
\hline Const. & $\begin{array}{l}.410 \\
(.681)\end{array}$ & $\begin{array}{l}.613 \\
(.792)\end{array}$ & $\begin{array}{l}.520 \\
(.828)\end{array}$ & $\begin{array}{l}1.112 \\
(.957)\end{array}$ & $\begin{array}{c}1.201 \\
(1.049)\end{array}$ \\
\hline Obs. & 391 & 366 & 366 & 279 & 279 \\
\hline$R^{2}$ & .842 & .847 & .849 & .852 & .854 \\
\hline BHC \& Year FE & Yes & Yes & Yes & Yes & Yes \\
\hline
\end{tabular}


Panel B: Impact of RMI on Tail Risk

\begin{tabular}{|c|c|c|c|c|c|}
\hline & \multicolumn{5}{|c|}{ Marginal Expected Shortfall (MES) } \\
\hline & $(1)$ & $(2)$ & $(3)$ & $(4)$ & $(5)$ \\
\hline $\mathrm{RMI}_{t-1}$ & $\begin{array}{c}-.074 \\
(.025)^{* * *}\end{array}$ & $\begin{array}{c}-.062 \\
(.025)^{* *}\end{array}$ & $\begin{array}{l}-.065 \\
(.027)^{* *}\end{array}$ & $\begin{array}{l}-.047 \\
(.036)\end{array}$ & \\
\hline Alt. $\mathrm{RMI}_{t-1}$ & & & & & $\begin{array}{c}-.072 \\
(.034)^{* *}\end{array}$ \\
\hline $\operatorname{Size}_{t-1}$ & $\begin{array}{c}.008 \\
(.003)^{* * *}\end{array}$ & $\begin{array}{c}.005 \\
(.003)^{*}\end{array}$ & $\begin{array}{c}.005 \\
(.003)^{*}\end{array}$ & $\begin{array}{l}.001 \\
(.004)\end{array}$ & $\begin{array}{l}.002 \\
(.004)\end{array}$ \\
\hline $\mathrm{ROA}_{t-1}$ & $\begin{array}{l}-.030 \\
(.102)\end{array}$ & $\begin{array}{l}-.035 \\
(.095)\end{array}$ & $\begin{array}{l}-.026 \\
(.091)\end{array}$ & $\begin{array}{l}-.150 \\
(.265)\end{array}$ & $\begin{array}{l}-.143 \\
(.276)\end{array}$ \\
\hline Annual Stock Return ${ }_{t-1}$ & $\begin{array}{l}-.003 \\
(.002)\end{array}$ & $\begin{array}{c}-.006 \\
(.003)^{* *}\end{array}$ & $\begin{array}{l}-.006 \\
(.003)^{* *}\end{array}$ & $\begin{array}{l}-.009 \\
(.004)^{* *}\end{array}$ & $\begin{array}{c}-.009 \\
(.003)^{* * *}\end{array}$ \\
\hline$(\text { Deposits/Assets })_{t-1}$ & $\begin{array}{l}.007 \\
(.017)\end{array}$ & $\begin{array}{l}.016 \\
(.015)\end{array}$ & $\begin{array}{l}.015 \\
(.015)\end{array}$ & $\begin{array}{c}.029 \\
(.017)^{*}\end{array}$ & $\begin{array}{c}.029 \\
(.017)^{*}\end{array}$ \\
\hline$(\text { Tier-1 Cap/Assets })_{t-1}$ & $\begin{array}{l}.011 \\
(.055)\end{array}$ & $\begin{array}{l}.043 \\
(.051)\end{array}$ & $\begin{array}{l}.046 \\
(.052)\end{array}$ & $\begin{array}{l}.058 \\
(.090)\end{array}$ & $\begin{array}{l}.055 \\
(.094)\end{array}$ \\
\hline$(\text { Loans/Assets })_{t-1}$ & $\begin{array}{l}-.002 \\
(.017)\end{array}$ & $\begin{array}{l}.0004 \\
(.018)\end{array}$ & $\begin{array}{l}.0008 \\
(.018)\end{array}$ & $\begin{array}{l}-.007 \\
(.022)\end{array}$ & $\begin{array}{l}-.009 \\
(.022)\end{array}$ \\
\hline$(\text { Bad Loans/Assets })_{t-1}$ & $\begin{array}{l}.354 \\
(.399)\end{array}$ & $\begin{array}{l}-.360 \\
(.379)\end{array}$ & $\begin{array}{l}-.352 \\
(.379)\end{array}$ & $\begin{array}{l}.166 \\
(.475)\end{array}$ & $\begin{array}{l}.118 \\
(.493)\end{array}$ \\
\hline (Non-int. Income/Income $)_{t-1}$ & $\begin{array}{l}-.010 \\
(.015)\end{array}$ & $\begin{array}{l}-.022 \\
(.021)\end{array}$ & $\begin{array}{l}-.023 \\
(.021)\end{array}$ & $\begin{array}{l}.0009 \\
(.024)\end{array}$ & $\begin{array}{l}.0007 \\
(.024)\end{array}$ \\
\hline$(\mathrm{UW} \text { Assets/Assets })_{t-1}$ & & $\begin{array}{l}-.055 \\
(.014)^{* * *}\end{array}$ & $\begin{array}{c}-.066 \\
(.019)^{* * *}\end{array}$ & $\begin{array}{l}-.030 \\
(.022)\end{array}$ & $\begin{array}{l}-.029 \\
(.021)\end{array}$ \\
\hline (Ins. Assets/Assets $)_{t-1}$ & & $\begin{array}{l}-.003 \\
(.005)\end{array}$ & $\begin{array}{l}-.003 \\
(.005)\end{array}$ & $\begin{array}{l}-.501 \\
(.371)\end{array}$ & $\begin{array}{l}-.388 \\
(.414)\end{array}$ \\
\hline Inst. Ownership ${ }_{t-1}$ & & $\begin{array}{c}.007 \\
(.011)\end{array}$ & $\begin{array}{l}.007 \\
(.011)\end{array}$ & $\begin{array}{l}.019 \\
(.018)\end{array}$ & $\begin{array}{l}.017 \\
(.017)\end{array}$ \\
\hline G-Index ${ }_{t-1}$ & & $\begin{array}{c}.0004 \\
(.0009)\end{array}$ & $\begin{array}{c}.0004 \\
(.0009)\end{array}$ & $\begin{array}{l}.001 \\
(.001)\end{array}$ & $\begin{array}{l}.001 \\
(.001)\end{array}$ \\
\hline$(\text { Deriv Trading/Assets })_{t-1}$ & & & $\begin{array}{c}.0004 \\
(.0005)\end{array}$ & $\begin{array}{c}-4.65 \mathrm{e}-06 \\
(.0004)\end{array}$ & $\begin{array}{l}.00006 \\
(.0004)\end{array}$ \\
\hline$(\text { Deriv Hedging/Assets })_{t-1}$ & & & $\begin{array}{c}-.0004 \\
(.006)\end{array}$ & $\begin{array}{l}-.003 \\
(.006)\end{array}$ & $\begin{array}{l}-.002 \\
(.005)\end{array}$ \\
\hline CEO's Delta $t-1$ & & & & $\begin{array}{c}-.130 \\
(.050)^{* * *}\end{array}$ & $\begin{array}{l}-.127 \\
(.050)^{* *}\end{array}$ \\
\hline CEO's Vega ${ }_{t-1}$ & & & & $\begin{array}{l}.0007 \\
(.003)\end{array}$ & $\begin{array}{l}.0005 \\
(.003)\end{array}$ \\
\hline Const. & $\begin{array}{l}-.088 \\
(.055)\end{array}$ & $\begin{array}{l}-.056 \\
(.052)\end{array}$ & $\begin{array}{l}-.052 \\
(.052)\end{array}$ & $\begin{array}{c}.057 \\
(.067)\end{array}$ & $\begin{array}{c}.063 \\
(.069)\end{array}$ \\
\hline Obs. & 603 & 484 & 484 & 321 & 321 \\
\hline$R^{2}$ & .852 & .9 & .9 & .92 & .921 \\
\hline BHC \& Year FE & Yes & Yes & Yes & Yes & Yes \\
\hline
\end{tabular}


Panel C: Impact of RMI on Aggregate Risk

\begin{tabular}{|c|c|c|c|c|c|}
\hline & & ard Dev & of Wee & Excess $R$ & \\
\hline & (1) & $(2)$ & $(3)$ & $(4)$ & $(5)$ \\
\hline $\mathrm{RMI}_{t-1}$ & $\begin{array}{c}-.118 \\
(.030)^{* * *}\end{array}$ & $\begin{array}{c}-.089 \\
(.033)^{* * *}\end{array}$ & $\begin{array}{c}-.091 \\
(.035)^{* * *}\end{array}$ & $\begin{array}{c}-.071 \\
(.040)^{*}\end{array}$ & \\
\hline Alt. $\mathrm{RMI}_{t-1}$ & & & & & $\begin{array}{c}-.066 \\
(.030)^{* *}\end{array}$ \\
\hline $\operatorname{Size}_{t-1}$ & $\begin{array}{l}-.002 \\
(.002)\end{array}$ & $\begin{array}{l}-.005 \\
(.003)\end{array}$ & $\begin{array}{l}-.005 \\
(.003)\end{array}$ & $\begin{array}{l}-.007 \\
(.005)\end{array}$ & $\begin{array}{l}-.006 \\
(.005)\end{array}$ \\
\hline $\mathrm{ROA}_{t-1}$ & $\begin{array}{c}-.265 \\
(.115)^{* *}\end{array}$ & $\begin{array}{c}-.303 \\
(.132)^{* *}\end{array}$ & $\begin{array}{c}-.296 \\
(.121)^{* *}\end{array}$ & $\begin{array}{l}-.034 \\
(.291)\end{array}$ & $\begin{array}{l}-.029 \\
(.308)\end{array}$ \\
\hline Annual Stock Return ${ }_{t-1}$ & $\begin{array}{c}-.008 \\
(.003)^{* * *}\end{array}$ & $\begin{array}{c}-.011 \\
(.003)^{* * *}\end{array}$ & $\begin{array}{c}-.011 \\
(.004)^{* * *}\end{array}$ & $\begin{array}{c}-.010 \\
(.004)^{* *}\end{array}$ & $\begin{array}{c}-.010 \\
(.004)^{* *}\end{array}$ \\
\hline$(\text { Deposits/Assets })_{t-1}$ & $\begin{array}{l}.011 \\
(.021)\end{array}$ & $\begin{array}{l}.022 \\
(.018)\end{array}$ & $\begin{array}{l}.022 \\
(.018)\end{array}$ & $\begin{array}{l}.017 \\
(.025)\end{array}$ & $\begin{array}{l}.017 \\
(.025)\end{array}$ \\
\hline$(\text { Tier-1 Cap/Assets })_{t-1}$ & $\begin{array}{l}.027 \\
(.065)\end{array}$ & $\begin{array}{l}.044 \\
(.062)\end{array}$ & $\begin{array}{l}.045 \\
(.061)\end{array}$ & $\begin{array}{l}-.058 \\
(.087)\end{array}$ & $\begin{array}{l}-.069 \\
(.088)\end{array}$ \\
\hline$(\text { Loans/Assets })_{t-1}$ & $\begin{array}{c}-.027 \\
(.016)^{*}\end{array}$ & $\begin{array}{l}-.019 \\
(.019)\end{array}$ & $\begin{array}{l}-.018 \\
(.019)\end{array}$ & $\begin{array}{l}-.025 \\
(.026)\end{array}$ & $\begin{array}{l}-.026 \\
(.026)\end{array}$ \\
\hline$(\text { Bad Loans/Assets })_{t-1}$ & $\begin{array}{c}.835 \\
(.569)\end{array}$ & $\begin{array}{c}.985 \\
(.666)\end{array}$ & $\begin{array}{c}.991 \\
(.664)\end{array}$ & $\begin{array}{c}.887 \\
(.496)^{*}\end{array}$ & $\begin{array}{c}.851 \\
(.508)^{*}\end{array}$ \\
\hline (Non-int. Income/Income $)_{t-1}$ & $\begin{array}{l}-.032 \\
(.022)\end{array}$ & $\begin{array}{l}-.035 \\
(.027)\end{array}$ & $\begin{array}{l}-.035 \\
(.027)\end{array}$ & $\begin{array}{l}-.010 \\
(.020)\end{array}$ & $\begin{array}{l}-.010 \\
(.020)\end{array}$ \\
\hline$(\mathrm{UW} \mathrm{Assets} / \text { Assets })_{t-1}$ & & $\begin{array}{c}.041 \\
(.017)^{* *}\end{array}$ & $\begin{array}{c}.034 \\
(.017)^{* *}\end{array}$ & $\begin{array}{l}-.025 \\
(.031)\end{array}$ & $\begin{array}{l}-.020 \\
(.031)\end{array}$ \\
\hline$(\text { Ins. Assets } / \text { Assets })_{t-1}$ & & $\begin{array}{l}-.009 \\
(.006)\end{array}$ & $\begin{array}{l}-.009 \\
(.006)\end{array}$ & $\begin{array}{l}.353 \\
(.535)\end{array}$ & $\begin{array}{l}.289 \\
(.607)\end{array}$ \\
\hline Inst. Ownership $t_{t-1}$ & & $\begin{array}{l}.024 \\
(.015)\end{array}$ & $\begin{array}{c}.025 \\
(.015)^{*}\end{array}$ & $\begin{array}{l}.037 \\
(.023)^{*}\end{array}$ & $\begin{array}{c}.037 \\
(.021)^{*}\end{array}$ \\
\hline G-Index $t-1$ & & $\begin{array}{l}.0004 \\
(.001)\end{array}$ & $\begin{array}{l}.0004 \\
(.001)\end{array}$ & $\begin{array}{l}.002 \\
(.001)\end{array}$ & $\begin{array}{c}.002 \\
(.001)^{*}\end{array}$ \\
\hline$(\text { Deriv Trading/Assets) })_{t-1}$ & & & $\begin{array}{l}.0003 \\
(.0005)\end{array}$ & $\begin{array}{l}.0003 \\
(.0004)\end{array}$ & $\begin{array}{l}.0002 \\
(.0003)\end{array}$ \\
\hline$(\text { Deriv Hedging/Assets })_{t-1}$ & & & $\begin{array}{l}.0003 \\
(.006)\end{array}$ & $\begin{array}{l}-.003 \\
(.006)\end{array}$ & $\begin{array}{l}-.001 \\
(.006)\end{array}$ \\
\hline CEO's Delta $t-1$ & & & & $\begin{array}{l}-.101 \\
(.067)\end{array}$ & $\begin{array}{l}-.093 \\
(.064)\end{array}$ \\
\hline CEO's Vega ${ }_{t-1}$ & & & & $\begin{array}{l}-.007 \\
(.004)^{*}\end{array}$ & $\begin{array}{c}-.008 \\
(.004)^{* *}\end{array}$ \\
\hline Const. & $\begin{array}{c}.156 \\
(.049)^{* * *}\end{array}$ & $\begin{array}{c}.162 \\
(.061)^{* * *}\end{array}$ & $\begin{array}{c}.165 \\
(.062)^{* * *}\end{array}$ & $\begin{array}{c}.207 \\
(.093)^{* *}\end{array}$ & $\begin{array}{c}.198 \\
(.090)^{* *}\end{array}$ \\
\hline Obs. & 604 & 484 & 484 & 321 & 321 \\
\hline$R^{2}$ & .8 & .838 & .838 & .868 & .867 \\
\hline BHC \& Year FE & Yes & Yes & Yes & Yes & Yes \\
\hline
\end{tabular}




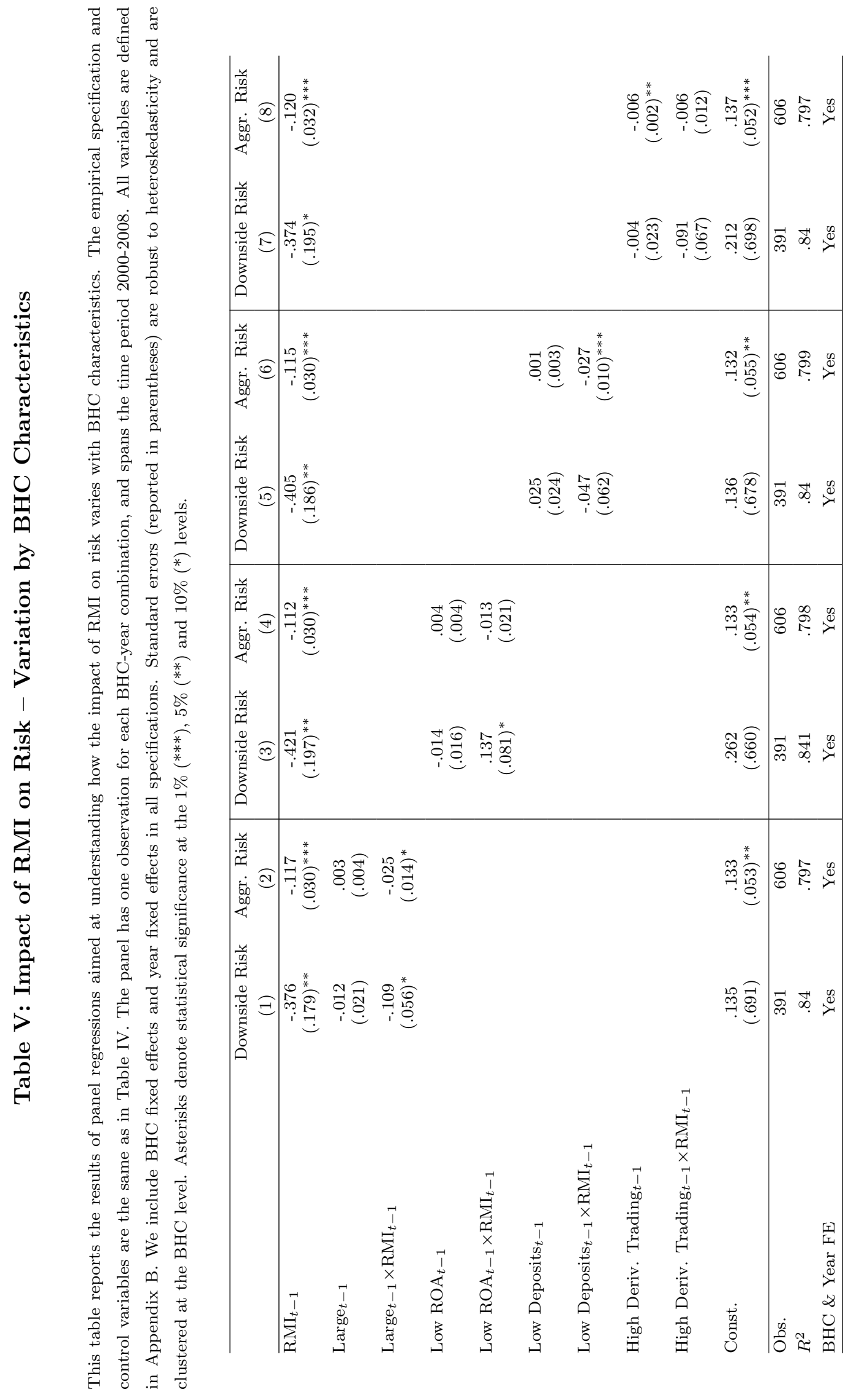




\section{Table VI: Dynamic Panel GMM Estimation for the Relationship between Risk and RMI}

This table reports the results of a dynamic panel GMM estimator developed by Arellano and Bond (1991), which seeks to understand the impact of lagged RMI on enterprise-wide risk. Variable definitions are in Appendix B. Asterisks denote statistical significance at the $1 \%(* * *), 5 \%(* *)$ and $10 \%(*)$ levels.

\begin{tabular}{|c|c|c|c|c|}
\hline \multirow[t]{2}{*}{ Y Variable $=$} & \multicolumn{2}{|c|}{ Downside Risk } & Tail Risk & Aggregate Risk \\
\hline & $(1)$ & $(2)$ & $(3)$ & $(4)$ \\
\hline $\mathrm{RMI}_{t-1}$ & $\begin{array}{l}-2.528 \\
(.160)^{* * *}\end{array}$ & $\begin{array}{l}-1.995 \\
(.334)^{* * *}\end{array}$ & $\begin{array}{c}-.135 \\
(.025)^{* * *}\end{array}$ & $\begin{array}{c}-.285 \\
(.017)^{* * *}\end{array}$ \\
\hline $\mathrm{Y}_{t-1}$ & $\begin{array}{c}-.255 \\
(.049)^{* * *}\end{array}$ & $\begin{array}{c}-.380 \\
(.060)^{* * *}\end{array}$ & $\begin{array}{c}1.062 \\
(.099)^{* * *}\end{array}$ & $\begin{array}{l}.074 \\
(.088)\end{array}$ \\
\hline $\mathrm{Y}_{t-2}$ & $\begin{array}{c}-.666 \\
(.038)^{* * *}\end{array}$ & $\begin{array}{c}-.799 \\
(.046)^{* * *}\end{array}$ & $\begin{array}{c}-.620 \\
(.075)^{* * *}\end{array}$ & $\begin{array}{l}-.554 \\
(.058)^{* * *}\end{array}$ \\
\hline Size $_{t-1}$ & $\begin{array}{l}-.002 \\
(.028)\end{array}$ & $\begin{array}{c}-.125 \\
(.035)^{* * *}\end{array}$ & $\begin{array}{c}.017 \\
(.004)^{* * *}\end{array}$ & $\begin{array}{c}-.018 \\
(.006)^{* * *}\end{array}$ \\
\hline $\mathrm{ROA}_{t-1}$ & $\begin{array}{l}-.074 \\
(.324)\end{array}$ & $\begin{array}{c}-16.054 \\
(6.695)^{* *}\end{array}$ & $\begin{array}{c}-.858 \\
(.306)^{* * *}\end{array}$ & $\begin{array}{l}-1.256 \\
(.241)^{* * *}\end{array}$ \\
\hline Annual Stock Return $\operatorname{R}_{t-1}$ & $\begin{array}{c}-.134 \\
(.016)^{* * *}\end{array}$ & $\begin{array}{c}-.128 \\
(.030)^{* * *}\end{array}$ & $\begin{array}{l}.005 \\
(.002)^{*}\end{array}$ & $\begin{array}{c}-.012 \\
(.002)^{* * *}\end{array}$ \\
\hline$(\text { Deposits/Assets })_{t-1}$ & $\begin{array}{l}-.242 \\
(.112)^{* *}\end{array}$ & $\begin{array}{l}-.205 \\
(.220)\end{array}$ & $\begin{array}{l}.036 \\
(.027)\end{array}$ & $\begin{array}{l}-.044 \\
(.022)^{* *}\end{array}$ \\
\hline$(\text { Tier-1 Cap/Assets })_{t-1}$ & $\begin{array}{l}-1.536 \\
(.309)^{* * *}\end{array}$ & $\begin{array}{l}-1.874 \\
(3.377)\end{array}$ & $\begin{array}{l}-.062 \\
(.118)\end{array}$ & $\begin{array}{c}-.322 \\
(.114)^{* * *}\end{array}$ \\
\hline$(\text { Loans/Assets })_{t-1}$ & $\begin{array}{l}.015 \\
(.122)\end{array}$ & $\begin{array}{l}-.421 \\
(.393)\end{array}$ & $\begin{array}{c}.068 \\
(.015)^{* * *}\end{array}$ & $\begin{array}{c}.059 \\
(.019)^{* * *}\end{array}$ \\
\hline (Bad Loans/Assets) $t-1$ & $\begin{array}{c}33.696 \\
(1.672)^{* * *}\end{array}$ & $\begin{array}{c}29.243 \\
(4.046)^{* * *}\end{array}$ & $\begin{array}{c}2.555 \\
(.334)^{* * *}\end{array}$ & $\begin{array}{l}3.982 \\
(.586)^{* * *}\end{array}$ \\
\hline (Non-int. income/Income $)_{t-1}$ & $\begin{array}{l}.074 \\
(.062)\end{array}$ & $\begin{array}{c}.343 \\
(.165)^{* *}\end{array}$ & $\begin{array}{l}-.019 \\
(.015)\end{array}$ & $\begin{array}{l}-.019 \\
(.012)\end{array}$ \\
\hline$\left(\mathrm{UW}\right.$ Assets/Assets) ${ }_{t-1}$ & $\begin{array}{c}-.519 \\
(.160)^{* * *}\end{array}$ & $\begin{array}{l}-1.062 \\
(.450)^{* *}\end{array}$ & $\begin{array}{l}-.025 \\
(.032)\end{array}$ & $\begin{array}{c}-.083 \\
(.025)^{* * *}\end{array}$ \\
\hline (Ins. Assets/Assets $)_{t-1}$ & $\begin{array}{l}.507 \\
(.469)\end{array}$ & $\begin{array}{l}-6.763 \\
(30.004)\end{array}$ & $\begin{array}{l}-.944 \\
(2.356)\end{array}$ & $\begin{array}{l}-1.764 \\
(2.719)\end{array}$ \\
\hline Inst. Ownership $t-1$ & $\begin{array}{c}.964 \\
(.080)^{* * *}\end{array}$ & $\begin{array}{c}1.164 \\
(.106)^{* * *}\end{array}$ & $\begin{array}{c}.114 \\
(.017)^{* * *}\end{array}$ & $\begin{array}{c}.163 \\
(.017)^{* * *}\end{array}$ \\
\hline G-Index $t-1$ & $\begin{array}{l}-.027 \\
(.013)^{* *}\end{array}$ & $\begin{array}{l}-.025 \\
(.012)^{* *}\end{array}$ & $\begin{array}{l}-.0004 \\
(.001)\end{array}$ & $\begin{array}{l}-.0007 \\
(.002)\end{array}$ \\
\hline (Deriv Trading/Assets) ${ }_{t-1}$ & $\begin{array}{c}.019 \\
(.002)^{* * *}\end{array}$ & $\begin{array}{c}.030 \\
(.010)^{* * *}\end{array}$ & $\begin{array}{c}.002 \\
(.0007)^{* * *}\end{array}$ & $\begin{array}{c}.002 \\
(.0009)^{* *}\end{array}$ \\
\hline (Deriv Hedging/Assets) $t-1$ & $\begin{array}{l}.010 \\
(.039)\end{array}$ & $\begin{array}{l}.118 \\
(.061)^{*}\end{array}$ & $\begin{array}{l}.003 \\
(.006)\end{array}$ & $\begin{array}{l}-.007 \\
(.006)\end{array}$ \\
\hline CEO's Delta $t-1$ & & $\begin{array}{l}.137 \\
(1.204)\end{array}$ & $\begin{array}{l}-.013 \\
(.091)\end{array}$ & $\begin{array}{l}-.145 \\
(.079)^{*}\end{array}$ \\
\hline CEO's Vegat $t-1$ & & $\begin{array}{l}.059 \\
(.035)^{*}\end{array}$ & $\begin{array}{c}.027 \\
(.004)^{* * *}\end{array}$ & $\begin{array}{c}.013 \\
(.003)^{* * *}\end{array}$ \\
\hline Obs. & 215 & 164 & 234 & 234 \\
\hline Sargan $\chi^{2}$ & 33.747 & 24.426 & 35.766 & 34.886 \\
\hline Sargan p-value & 0.142 & 0.607 & 0.432 & 0.474 \\
\hline
\end{tabular}




\section{Table VII: Impact of CRO Centrality and Quality of Risk Oversight}

Panel A reports the results of cross-sectional regressions that examine whether BHCs with high CRO Centrality and Quality of Oversight in 2006 fared better during the crisis years. The empirical specification and control variables are the same as in Table III. Asterisks denote statistical significance at the $1 \%(* * *), 5 \%$ $(* *)$ and $10 \%(*)$ levels.

Panel A: Performance during Crisis Years, 2007-08

\begin{tabular}{|c|c|c|c|c|c|c|}
\hline & Private MBS & Trading Assets & Deriv. & Downside Risk & Tail Risk & Aggregate Risk \\
\hline & $(1)$ & $(2)$ & $(3)$ & $(4)$ & $(5)$ & $(6)$ \\
\hline$\overline{\mathrm{CRO}}$ Centrality 2006 & $\begin{array}{l}-8.534 \\
(9.173)\end{array}$ & $\begin{array}{l}-41.974 \\
(57.326)\end{array}$ & $\begin{array}{c}3.635 \\
(6.895)\end{array}$ & $\begin{array}{c}-.355 \\
(.157)^{* *}\end{array}$ & $\begin{array}{c}-.031 \\
(.017)^{*}\end{array}$ & $\begin{array}{c}-.073 \\
(.020)^{* * *}\end{array}$ \\
\hline Quality of Oversight 2006 & $\begin{array}{c}-4.286 \\
(1.888)^{* *}\end{array}$ & $\begin{array}{c}-21.096 \\
(10.767)^{*}\end{array}$ & $\begin{array}{c}-2.624 \\
(1.400)^{*}\end{array}$ & $\begin{array}{l}-.026 \\
(.044)\end{array}$ & $\begin{array}{l}.0007 \\
(.005)\end{array}$ & $\begin{array}{l}-.007 \\
(.006)\end{array}$ \\
\hline Size $_{2006}$ & $\begin{array}{c}5.819 \\
(1.548)^{* * *}\end{array}$ & $\begin{array}{c}34.183 \\
(10.541)^{* * *}\end{array}$ & $\begin{array}{c}4.920 \\
(1.551)^{* * *}\end{array}$ & $\begin{array}{l}-.013 \\
(.012)\end{array}$ & $\begin{array}{c}.004 \\
(.002)^{* *}\end{array}$ & $\begin{array}{l}.002 \\
(.002)\end{array}$ \\
\hline $\mathrm{ROA}_{2006}$ & $\begin{array}{c}32.543 \\
(111.178)\end{array}$ & $\begin{array}{c}-1052.956 \\
(831.009)\end{array}$ & $\begin{array}{l}-236.959 \\
(160.879)\end{array}$ & $\begin{array}{l}-3.866 \\
(3.691)\end{array}$ & $\begin{array}{l}-.057 \\
(.354)\end{array}$ & $\begin{array}{l}-.741 \\
(.508)\end{array}$ \\
\hline (Tier-1 Cap./Assets) 2006 & $\begin{array}{c}-9.738 \\
(41.686)\end{array}$ & $\begin{array}{c}340.239 \\
(257.881)\end{array}$ & $\begin{array}{c}75.820 \\
(48.976)\end{array}$ & $\begin{array}{c}.716 \\
(1.060)\end{array}$ & $\begin{array}{l}.018 \\
(.106)\end{array}$ & $\begin{array}{l}.140 \\
(.146)\end{array}$ \\
\hline$($ Bad Loans/Assets) 2006 & $\begin{array}{c}5.067 \\
(142.218)\end{array}$ & $\begin{array}{l}-599.640 \\
(798.399)\end{array}$ & $\begin{array}{l}-126.476 \\
(125.061)\end{array}$ & $\begin{array}{c}12.672 \\
(5.482)^{* *}\end{array}$ & $\begin{array}{l}.490 \\
(.578)\end{array}$ & $\begin{array}{l}1.167 \\
(.821)\end{array}$ \\
\hline$($ Deposits/Assets) 2006 & $\begin{array}{l}4.569 \\
(7.487)\end{array}$ & $\begin{array}{c}60.927 \\
(44.809)\end{array}$ & $\begin{array}{l}10.859 \\
(7.259)\end{array}$ & $\begin{array}{c}.069 \\
(.131)\end{array}$ & $\begin{array}{l}-.030 \\
(.016)^{*}\end{array}$ & $\begin{array}{l}-.020 \\
(.014)\end{array}$ \\
\hline$\left(\right.$ Loans/Assets) ${ }_{2006}$ & $\begin{array}{c}-10.995 \\
(3.843)^{* * *}\end{array}$ & $\begin{array}{l}-55.297 \\
(36.204)\end{array}$ & $\begin{array}{l}-9.098 \\
(6.391)\end{array}$ & $\begin{array}{l}-.215 \\
(.143)\end{array}$ & $\begin{array}{l}.020 \\
(.015)\end{array}$ & $\begin{array}{l}.006 \\
(.015)\end{array}$ \\
\hline Const. & $\begin{array}{c}-87.488 \\
(27.856)^{* * *}\end{array}$ & $\begin{array}{c}-564.042 \\
(183.723)^{* * *}\end{array}$ & $\begin{array}{c}-86.008 \\
(29.938)^{* * *}\end{array}$ & $\begin{array}{c}1.079 \\
(.249)^{* * *}\end{array}$ & $\begin{array}{l}-.018 \\
(.037)\end{array}$ & $\begin{array}{c}.084 \\
(.042)^{* *}\end{array}$ \\
\hline$\overline{\text { Obs. }}$ & 143 & 143 & 143 & 112 & 140 & 141 \\
\hline$R^{2}$ & .521 & .364 & .323 & .665 & .638 & .584 \\
\hline Year FE & Yes & Yes & Yes & Yes & Yes & Yes \\
\hline
\end{tabular}


Panel B reports the results of panel regressions examining the impact of CRO Centrality $t_{-1}$ and Board Oversight $_{t-1}$ on enterprise-wide risk. The dependent variables in Columns (1), (2) and (3) are Downside Risk, Tail Risk, and Aggregate Risk, respectively. The panel, empirical specification, and control variables are the same as in Column (1) of Table IV. Asterisks denote statistical significance at the $1 \%(* * *), 5 \%(* *)$ and $10 \%(*)$ levels.

Panel B: Impact on Risk, 2000-2008

\begin{tabular}{|c|c|c|c|}
\hline \multirow[t]{2}{*}{ Dep. Variable $=$} & Downside Risk & Tail Risk & Aggregate Risk \\
\hline & $(1)$ & $(2)$ & $(3)$ \\
\hline CRO Centrality $_{t-1}$ & $\begin{array}{l}-.119 \\
(.105)\end{array}$ & $\begin{array}{l}-.022 \\
(.012)^{*}\end{array}$ & $\begin{array}{l}-.013 \\
(.014)\end{array}$ \\
\hline Quality of Oversight $t_{t-1}$ & $\begin{array}{c}-.040 \\
(.013)^{* * *}\end{array}$ & $\begin{array}{l}-.003 \\
(.002)\end{array}$ & $\begin{array}{l}-.004 \\
(.002)^{*}\end{array}$ \\
\hline $\operatorname{Size}_{t-1}$ & $\begin{array}{l}.002 \\
(.032)\end{array}$ & $\begin{array}{c}.007 \\
(.002)^{* * *}\end{array}$ & $\begin{array}{l}-.002 \\
(.002)\end{array}$ \\
\hline $\mathrm{ROA}_{t-1}$ & $\begin{array}{l}-1.228 \\
(1.090)\end{array}$ & $\begin{array}{l}-.032 \\
(.092)\end{array}$ & $\begin{array}{c}-.262 \\
(.109)^{* *}\end{array}$ \\
\hline Annual Stock Return ${ }_{t-1}$ & $\begin{array}{c}-.069 \\
(.019)^{* * *}\end{array}$ & $\begin{array}{c}-.003 \\
(.002)^{*}\end{array}$ & $\begin{array}{c}-.009 \\
(.003)^{* * *}\end{array}$ \\
\hline$(\text { Deposits/Assets })_{t-1}$ & $\begin{array}{c}.280 \\
(.120)^{* *}\end{array}$ & $\begin{array}{c}.008 \\
(.014)\end{array}$ & $\begin{array}{c}.013 \\
(.017)\end{array}$ \\
\hline$(\text { Tier-1 Cap/Assets })_{t-1}$ & $\begin{array}{l}-.271 \\
(.570)\end{array}$ & $\begin{array}{c}.007 \\
(.045)\end{array}$ & $\begin{array}{c}.014 \\
(.054)\end{array}$ \\
\hline (Loans/Assets) $)_{t-1}$ & $\begin{array}{l}-.101 \\
(.101)\end{array}$ & $\begin{array}{l}-.005 \\
(.012)\end{array}$ & $\begin{array}{c}-.031 \\
(.014)^{* *}\end{array}$ \\
\hline$(\text { Bad Loans/Assets })_{t-1}$ & $\begin{array}{c}9.046 \\
(1.815)^{* * *}\end{array}$ & $\begin{array}{l}.483 \\
(.307)\end{array}$ & $\begin{array}{c}1.091 \\
(.398)^{* * *}\end{array}$ \\
\hline (Non-int. income/Income $)_{t-1}$ & $\begin{array}{c}.039 \\
(.113)\end{array}$ & $\begin{array}{l}-.012 \\
(.016)\end{array}$ & $\begin{array}{l}-.034 \\
(.021)\end{array}$ \\
\hline Const. & $\begin{array}{l}.306 \\
(.605)\end{array}$ & $\begin{array}{c}-.103 \\
(.043)^{* *}\end{array}$ & $\begin{array}{c}.116 \\
(.047)^{* *}\end{array}$ \\
\hline Obs. & 392 & 602 & 603 \\
\hline$R^{2}$ & .853 & .852 & .797 \\
\hline BHC \& Year FE & Yes & Yes & Yes \\
\hline
\end{tabular}




\section{Table VIII: Impact of RMI on Risk-Adjusted Returns}

This table reports the results of panel regressions investigating the impact of $R M I_{t-1}$ on Sharpe Ratiot. The panel has one observation for each BHC-year combination, and spans the time period 2000-2008. All variables are defined in Appendix B. We include BHC fixed effects and year fixed effects in all specifications. Standard errors (reported in parentheses) are robust to heteroskedasticity and are clustered at the BHC level. Asterisks denote statistical significance at the $1 \%(* * *), 5 \%(* *)$ and $10 \%(*)$ levels. 


\begin{tabular}{|c|c|c|c|c|c|}
\hline & \multicolumn{5}{|c|}{ Dep. variable $=$ Sharpe Ratio } \\
\hline & \multicolumn{4}{|c|}{ Panel Regression } & \multirow{2}{*}{$\begin{array}{c}\text { Arellano-Bond } \\
(5)\end{array}$} \\
\hline & $(1)$ & $(2)$ & (3) & $(4)$ & \\
\hline $\mathrm{RMI}_{t-1}$ & $\begin{array}{c}.208 \\
(.068)^{* * *}\end{array}$ & $\begin{array}{c}.198 \\
(.071)^{* * *}\end{array}$ & $\begin{array}{c}.242 \\
(.078)^{* * *}\end{array}$ & $\begin{array}{c}.233 \\
(.099)^{* *}\end{array}$ & $\begin{array}{c}.787 \\
(.063)^{* * *}\end{array}$ \\
\hline Pre-Crisis & & $\begin{array}{l}.015 \\
(.015)\end{array}$ & & & \\
\hline $\mathrm{RMI}_{t-1} \times$ Pre-crisis & & $\begin{array}{c}.036 \\
(.016)^{* *}\end{array}$ & & & \\
\hline Sharpe Ratio $_{t-1}$ & & & & & $\begin{array}{c}-.513 \\
(.044)^{* * *}\end{array}$ \\
\hline Sharpe Ratio ${ }_{t-2}$ & & & & & $\begin{array}{c}-.340 \\
(.037)^{* * *}\end{array}$ \\
\hline $\operatorname{Size}_{t-1}$ & $\begin{array}{c}-.036 \\
(.010)^{* * *}\end{array}$ & $\begin{array}{c}-.037 \\
(.010)^{* * *}\end{array}$ & $\begin{array}{c}-.049 \\
(.012)^{* * *}\end{array}$ & $\begin{array}{c}-.048 \\
(.012)^{* * *}\end{array}$ & $\begin{array}{c}-.113 \\
(.012)^{* * *}\end{array}$ \\
\hline $\mathrm{ROA}_{t-1}$ & $\begin{array}{c}-1.126 \\
(.379)^{* * *}\end{array}$ & $\begin{array}{c}-1.176 \\
(.388)^{* * *}\end{array}$ & $\begin{array}{c}-1.038 \\
(.399)^{* * *}\end{array}$ & $\begin{array}{l}-1.614 \\
(1.044)\end{array}$ & $\begin{array}{l}-1.980 \\
(1.298)\end{array}$ \\
\hline$(\text { Deposits/Assets })_{t-1}$ & $\begin{array}{c}.001 \\
(.040)\end{array}$ & $\begin{array}{c}.008 \\
(.039)\end{array}$ & $\begin{array}{l}-.015 \\
(.048)\end{array}$ & $\begin{array}{c}.037 \\
(.056)\end{array}$ & $\begin{array}{c}.019 \\
(.053)\end{array}$ \\
\hline$(\text { Tier-1 Cap/Assets })_{t-1}$ & $\begin{array}{c}.107 \\
(.206)\end{array}$ & $\begin{array}{c}.119 \\
(.208)\end{array}$ & $\begin{array}{c}.131 \\
(.227)\end{array}$ & $\begin{array}{l}-.609 \\
(.465)\end{array}$ & $\begin{array}{l}-.892 \\
(.618)\end{array}$ \\
\hline$(\text { Loans/Assets })_{t-1}$ & $\begin{array}{l}-.013 \\
(.039)\end{array}$ & $\begin{array}{l}-.020 \\
(.040)\end{array}$ & $\begin{array}{l}-.076 \\
(.047)\end{array}$ & $\begin{array}{l}-.089 \\
(.058)\end{array}$ & $\begin{array}{c}-.248 \\
(.050)^{* * *}\end{array}$ \\
\hline$(\text { Bad Loans/Assets })_{t-1}$ & $\begin{array}{c}1.174 \\
(.679)^{*}\end{array}$ & $\begin{array}{c}.995 \\
(.709)\end{array}$ & $\begin{array}{c}1.635 \\
(.977)^{*}\end{array}$ & $\begin{array}{c}1.912 \\
(1.481)\end{array}$ & $\begin{array}{c}4.320 \\
(1.850)^{* *}\end{array}$ \\
\hline (Non-int. income/Income $)_{t-1}$ & $\begin{array}{c}.059 \\
(.030)^{*}\end{array}$ & $\begin{array}{c}.050 \\
(.031)\end{array}$ & $\begin{array}{c}.066 \\
(.034)^{*}\end{array}$ & $\begin{array}{c}.104 \\
(.036)^{* * *}\end{array}$ & $\begin{array}{c}.260 \\
(.048)^{* * *}\end{array}$ \\
\hline$(\mathrm{UW} \mathrm{Assets/Assets})_{t-1}$ & $\begin{array}{c}.206 \\
(.081)^{* *}\end{array}$ & $\begin{array}{c}.209 \\
(.084)^{* *}\end{array}$ & $\begin{array}{c}.203 \\
(.098)^{* *}\end{array}$ & $\begin{array}{c}.095 \\
(.079)\end{array}$ & $\begin{array}{c}.167 \\
(.144)\end{array}$ \\
\hline (Ins. Assets/Assets) $)_{t-1}$ & $\begin{array}{c}.075 \\
(.007)^{* * *}\end{array}$ & $\begin{array}{c}.073 \\
(.007)^{* * *}\end{array}$ & $\begin{array}{c}.075 \\
(.008)^{* * *}\end{array}$ & $\begin{array}{c}1.925 \\
(2.441)\end{array}$ & $\begin{array}{l}-2.692 \\
(4.332)\end{array}$ \\
\hline Inst. Ownership $t-1$ & & & $\begin{array}{l}-.041 \\
(.036)\end{array}$ & $\begin{array}{l}-.025 \\
(.040)\end{array}$ & $\begin{array}{c}-.069 \\
(.040)^{*}\end{array}$ \\
\hline G-Index $t-1$ & & & $\begin{array}{c}.006 \\
(.004)\end{array}$ & $\begin{array}{c}.005 \\
(.004)\end{array}$ & $\begin{array}{l}.002 \\
(.005)\end{array}$ \\
\hline (Deriv Trading/Assets) $_{t-1}$ & & & $\begin{array}{l}.0003 \\
(.001)\end{array}$ & $\begin{array}{c}.002 \\
(.001)\end{array}$ & $\begin{array}{c}-.003 \\
(.002)^{*}\end{array}$ \\
\hline (Deriv Hedging/Assets) $_{t-1}$ & & & $\begin{array}{c}.011 \\
(.013)\end{array}$ & $\begin{array}{c}.019 \\
(.017)\end{array}$ & $\begin{array}{l}-.013 \\
(.023)\end{array}$ \\
\hline CEO's Delta $t-1$ & & & & $\begin{array}{c}.390 \\
(.227)^{*}\end{array}$ & $\begin{array}{l}-.115 \\
(.408)\end{array}$ \\
\hline CEO's Vega ${ }_{t-1}$ & & & & $\begin{array}{l}-.010 \\
(.014)\end{array}$ & $\begin{array}{c}-.044 \\
(.013)^{* * *}\end{array}$ \\
\hline Obs. & 606 & 606 & 484 & 321 & 234 \\
\hline$R^{2}$ & .597 & .6 & .644 & .683 & \\
\hline Sargan $\chi^{2}$ & & & & & 34.539 \\
\hline Sargan p-value & & & & & .490 \\
\hline
\end{tabular}

